\title{
Review \\ Cancer Epigenetic Biomarkers in Liquid Biopsy for High
Incidence Malignancies
}

\author{
Cora Palanca-Ballester ${ }^{1,+}{ }^{+}$, Aitor Rodriguez-Casanova ${ }^{2,3,+}$, Susana Torres ${ }^{4,5,6,+}{ }^{\dagger}$, Silvia Calabuig-Fariñas $4,5,6,7 \mathbb{1}$, \\ Francisco Exposito 4,8,9®0, Diego Serrano 8,9 (), Esther Redin 4,8,9, Karmele Valencia $4,8,10 \oplus$, \\ Eloisa Jantus-Lewintre $4,5,6,11 \mathbb{C}$, Angel Diaz-Lagares ${ }^{2,4}$, Luis Montuenga ${ }^{4,8,9} \mathbb{C}^{\mathbb{D}}$, Juan Sandoval ${ }^{1, *, \ddagger}$ \\ and Alfonso Calvo ${ }^{4,8,9, *, \ddagger}$
}

check for updates

Citation: Palanca-Ballester, C.; Rodriguez-Casanova, A.; Torres, S.; Calabuig-Fariñas, S.; Exposito, F.; Serrano, D.; Redin, E.; Valencia, K.; Jantus-Lewintre, E.; Diaz-Lagares, A.; et al. Cancer Epigenetic Biomarkers in Liquid Biopsy for High Incidence Malignancies. Cancers 2021, 13, 3016. https://doi.org/10.3390/

cancers13123016

Academic Editor: Fabrizio Bianchi

Received: 27 March 2021

Accepted: 11 June 2021

Published: 16 June 2021

Publisher's Note: MDPI stays neutral with regard to jurisdictional claims in published maps and institutional affiliations.

Copyright: (c) 2021 by the authors. Licensee MDPI, Basel, Switzerland. This article is an open access article distributed under the terms and conditions of the Creative Commons Attribution (CC BY) license (https:/ / creativecommons.org/licenses/by/ $4.0 /)$.
1 Biomarkers and Precision Medicine (UBMP) and Epigenomics Unit, IIS, La Fe, 46026 Valencia, Spain; cora_palanca@iislafe.es

2 Cancer Epigenomics, Translational Medical Oncology (Oncomet), Health Research Institute of Santiago (IDIS), University Clinical Hospital of Santiago (CHUS/SERGAS), 15706 Santiago de Compostela, Spain; aitorrodriguez@me.com (A.R.-C.); angel.diaz.lagares@sergas.es (A.D.-L.)

3 Roche-CHUS Joint Unit, Translational Medical Oncology Group (Oncomet), Health Research Institute of Santiago (IDIS), 15706 Santiago de Compostela, Spain

4 CIBERONC, ISCIII, 28029 Madrid, Spain; susana.torres@alu.umh.es (S.T.); calabuix_sil@gva.es (S.C.-F.); fexposito@unav.es (F.E.); eredin@alumni.unav.es (E.R.); kvalencia@external.unav.es (K.V.); jantus_elo@gva.es (E.J.-L.); lmontuenga@unav.es (L.M.)

5 Molecular Oncology Laboratory, Fundación Hospital General Universitario de Valencia, 46014 Valencia, Spain

6 TRIAL Mixed Unit, Centro de Investigación Príncipe Felipe-Fundación para la Investigación del Hospital General Universitario de Valencia, 46014 Valencia, Spain

7 Department of Pathology, Universitat de València, 46010 Valencia, Spain

8 DISNA and Program in Solid Tumors, Center for Applied Medical Research (CIMA), 31008 Pamplona, Spain; dserrano@unav.es

9 Department of Pathology, Anatomy and Physiology, School of Medicine, University of Navarra, 31008 Pamplona, Spain

10 Department of Biochemistry and Genetics, School of Sciences, University of Navarra, 31008 Pamplona, Spain

11 Department of Biotechnology, Universitat Politècnica de València, 46022 Valencia, Spain

* Correspondence: epigenomica@iislafe.es (J.S.); acalvo@unav.es (A.C.)

+ These authors contributed equally and should be considered as first authors.

$\ddagger$ Co-senior authors.

Simple Summary: Apart from genetic changes, cancer is characterized by epigenetic alterations, which indicate modifications in the DNA (such as DNA methylation) and histones (such as methylation and acetylation), as well as gene expression regulation by non-coding (nc)RNAs. These changes can be used in biological fluids (liquid biopsies) for diagnosis, prognosis and prediction of cancer drug response. Although these alterations are not widely used as biomarkers in the clinical practice yet, increasing number of commercial kits and clinical trials are expected to prove that epigenetic changes are able to offer valuable information for cancer patients.

Abstract: Early alterations in cancer include the deregulation of epigenetic events such as changes in DNA methylation and abnormal levels of non-coding (nc)RNAs. Although these changes can be identified in tumors, alternative sources of samples may offer advantages over tissue biopsies. Because tumors shed DNA, RNA, and proteins, biological fluids containing these molecules can accurately reflect alterations found in cancer cells, not only coming from the primary tumor, but also from metastasis and from the tumor microenvironment (TME). Depending on the type of cancer, biological fluids encompass blood, urine, cerebrospinal fluid, and saliva, among others. Such samples are named with the general term "liquid biopsy" (LB). With the advent of ultrasensitive technologies during the last decade, the identification of actionable genetic alterations (i.e., mutations) in LB is a common practice to decide whether or not targeted therapy should be applied. Likewise, the analysis of global or specific epigenetic alterations may also be important as biomarkers for diagnosis, prognosis, and even for cancer drug response. Several commercial kits that assess the DNA promoter methylation of single genes or gene sets are available, with some of them being tested as biomarkers 
for diagnosis in clinical trials. From the tumors with highest incidence, we can stress the relevance of DNA methylation changes in the following genes found in LB: SHOX2 (for lung cancer); RASSF1A, RARB2, and GSTP1 (for lung, breast, genitourinary and colon cancers); and SEPT9 (for colon cancer). Moreover, multi-cancer high-throughput methylation-based tests are now commercially available. Increased levels of the microRNA miR21 and several miRNA- and long ncRNA-signatures can also be indicative biomarkers in LB. Therefore, epigenetic biomarkers are attractive and may have a clinical value in cancer. Nonetheless, validation, standardization, and demonstration of an added value over the common clinical practice are issues needed to be addressed in the transfer of this knowledge from "bench to bedside".

Keywords: epigenetic biomarkers; cancer; DNA methylation; micro-RNAs

\section{Introduction}

Aberrant epigenetic changes are recognized as one of the key events leading to carcinogenesis [1]. Cancer cells harbor global epigenetic abnormalities in addition to genetic alterations. The use of "omic" techniques in recent years has allowed us to get a comprehensive view of the extensive reprograming that occurs in the epigenetic machinery of cancer cells. These epigenetic changes include DNA methylation, histone modifications, nucleosome positioning, and de-regulation of non-coding RNAs, mainly micro-RNAs (miRNAs) [2].

The most widely studied epigenetic modification and the one closer to be transferred to the clinic as a cancer biomarker is DNA methylation. This modification is the result of the addition of a methyl group at the $5^{\prime}$-carbon of the pyrimidine ring of a cytosine followed by a guanine $(\mathrm{CpG})$, which impedes gene transcription. Cancer is characterized by global DNA hypomethylation and focal hypermethylation of certain genes such as tumor suppressor genes [3] or miRNAs, whose silencing promotes tumor growth [4]. Hypomethylation takes place mainly in repetitive regions of the genome and has been shown to facilitate genomic instability and DNA damage [5].

Both genetic and epigenetic alterations identified in cancer can be used as biomarkers for diagnosis, prognosis, and prediction of drug response. Although assessment of biomarkers in tumor specimens may offer direct information about genetic and epigenetic alterations, the amount of tissue obtained from advanced tumors is often insufficient and may not reflect the whole tumor heterogeneity. To overcome these inconveniences, an alternative option to tissue samples has emerged in the last years, known as liquid biopsy (LB). LB is an non-invasive method that allows for the analysis of different biomarkers in fluids such as blood, saliva, bronchoalveolar lavage (BAL), cerebrospinal fluid (CSF), urine, or other body fluids [6]. These samples are easily obtained and may pick up DNA/RNA/proteins coming from both the primary tumor and the different metastatic sites, representing tumor heterogeneity and clonal evolution. In LB, we can find circulating tumor DNA (ctDNA), circulating tumor RNA (ctRNA), circulating tumor cells (CTCs), and extracellular vesicles (EVs) that may contain RNA, proteins, and DNA. Figure 1 graphically depicts the possible contribution of epigenetic biomarkers (free or vesicle-enclosed methylated DNA and ncRNAs) isolated in LB, in conjunction with clinical data, for patient's stratification, prognosis, and prediction of response to therapy [6]. 


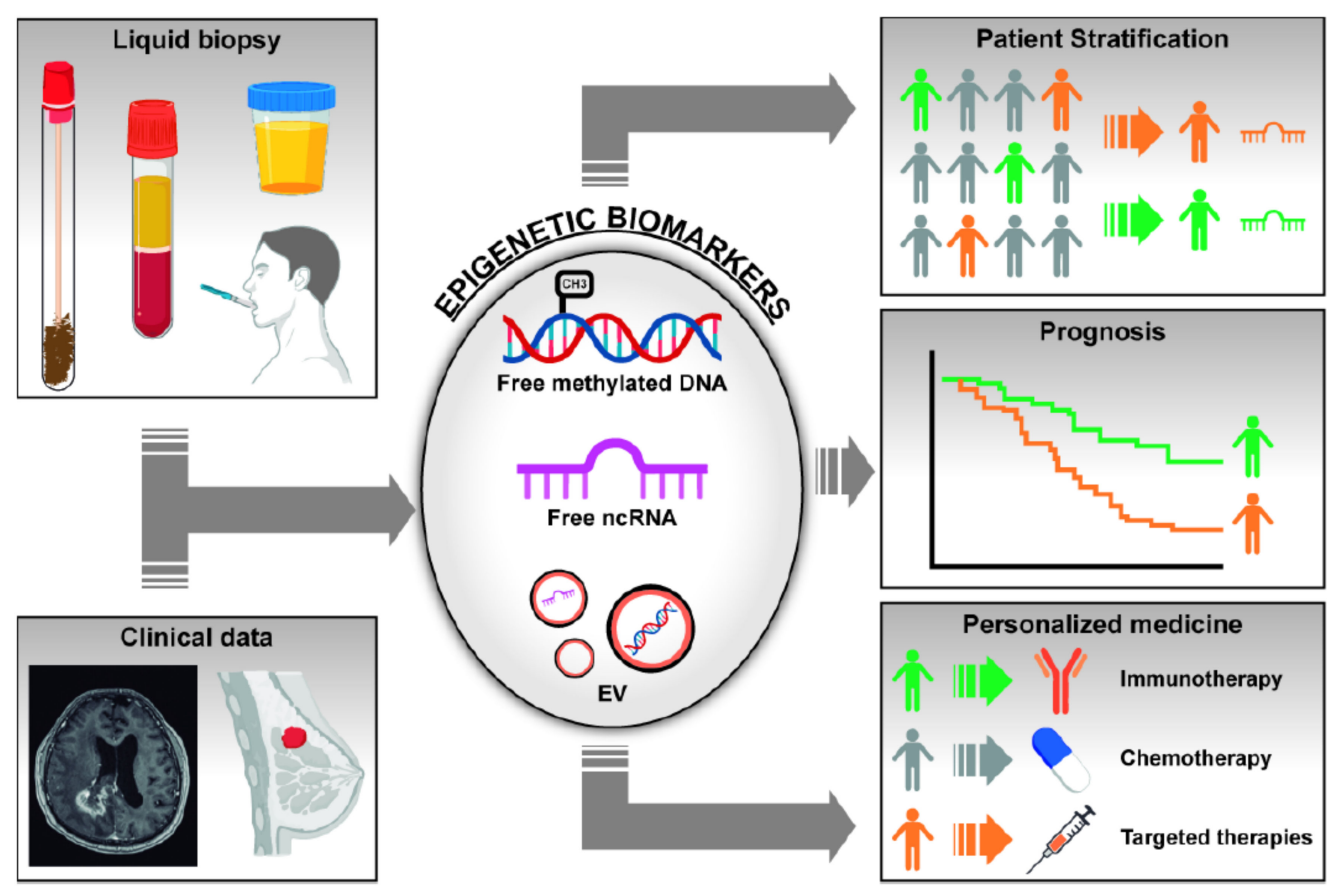

Figure 1. Scheme representing the utility of epigenetic changes found in liquid biopsies as biomarkers for cancer diagnosis, patient's stratification, prognosis, and response to treatments. Changes in DNA methylation of gene promoters and abnormal levels of non-coding RNAs (ncRNAs) can be found in fluids as free molecules or inside extracellular vesicles (EVs). Integration of these biological markers with clinical and radiological data may help in the management of cancer patients, in particular in the field of screening and diagnosis.

The clinical value of identifying actionable genetic mutations in LB (mainly blood) to treat patients with targeted therapy has been widely proven. However, regarding epigenetic changes, translation of these potential biomarkers into the clinic still lags far behind the genetic biomarkers. Although with some exceptions, rather than prediction of response to drugs, epigenetic biomarkers could be particularly useful as diagnostic and prognostic indicators, with numerous commercially available tests already developed to detect changes in DNA methylation levels [7]. The performance of diagnostic test is commonly evaluated in terms of sensitivity, specificity, and the area under the ROC curve (AUC). Sensitivity is defined as the percentage of positive cases that is correctly identified and specificity as the percentage of negative cases that is correctly identified. The AUC, which takes into account both sensitivity and specificity, defines diagnostic accuracy and is optimal when values are closer to 1 . The fact that epigenetic changes are found early in carcinogenesis and that DNA methylation is stable in ctDNA, makes this epigenetic modification an excellent potential cancer diagnostic biomarker in LB.

The term "epigenetic", considered as any change in gene expression that does not permanently affect the DNA, may also include gene expression regulation by non-coding (nc)RNAs and histone modifications [8]. The aberrantly expressed ncRNAs may be promising therapeutic targets as well as cancer biomarkers. ncRNAs are the principal regulators of key molecular and cellular processes such as RNA splicing, gene regulation, proliferation, and apoptosis. ncRNAs can be classified into two groups based on their length and their roles: housekeeping ncRNAs and regulatory ncRNAs, which in turn include small ncRNAs and long ncRNAs (Figure 2). Circulating RNA species can be found free in fluids or inside $\mathrm{EVs}$, where they are protected from degradation. EVs can be classified into three main types according to their size and biogenesis: exosomes, microvesicles, and apoptotic bodies [9]. Approximately $70 \%$ of studies have assessed exosomes as the source of choice for ncRNA when evaluating biomarkers [9]. Yuan et al. analyzed the RNA content in exosomes and estimated that mature miRNAs spanned $40.4 \%$, piwi-interacting RNAs $40 \%$, pseudo-genes $3.7 \%$, IncRNAs $2.4 \%$, tRNAs $2.1 \%$, and mRNAs $2.1 \%$ of the total RNA [10]. From the 
different species of ncRNAs, microRNAs stand out as potential epigenetic markers in fluids, although implementation in the clinic encounters several difficulties such as RNA instability and variability of the methodologies used [11]. In general, RNA is less stable than DNA and proteins, and in particular, some regulatory lncRNAs show short half-lives [12]. Besides, there are many factors that may influence RNA stability in body fluids such as hemolysis in plasma/serum samples, which are a major cause of variation in miRNA levels [13]. Another possible pitfall when analyzing tumor miRNAs in liquid biopsy is their unknown cellular origin and the masking effect from ncRNAs released by non-tumor cells. Several studies postulate that the material contained in exosomes derived from the tumor microenvironment (TME) can also contribute to the characterization of the tumor, and as a consequence, TME-derived exosomes could be a good source for biomarkers [14].

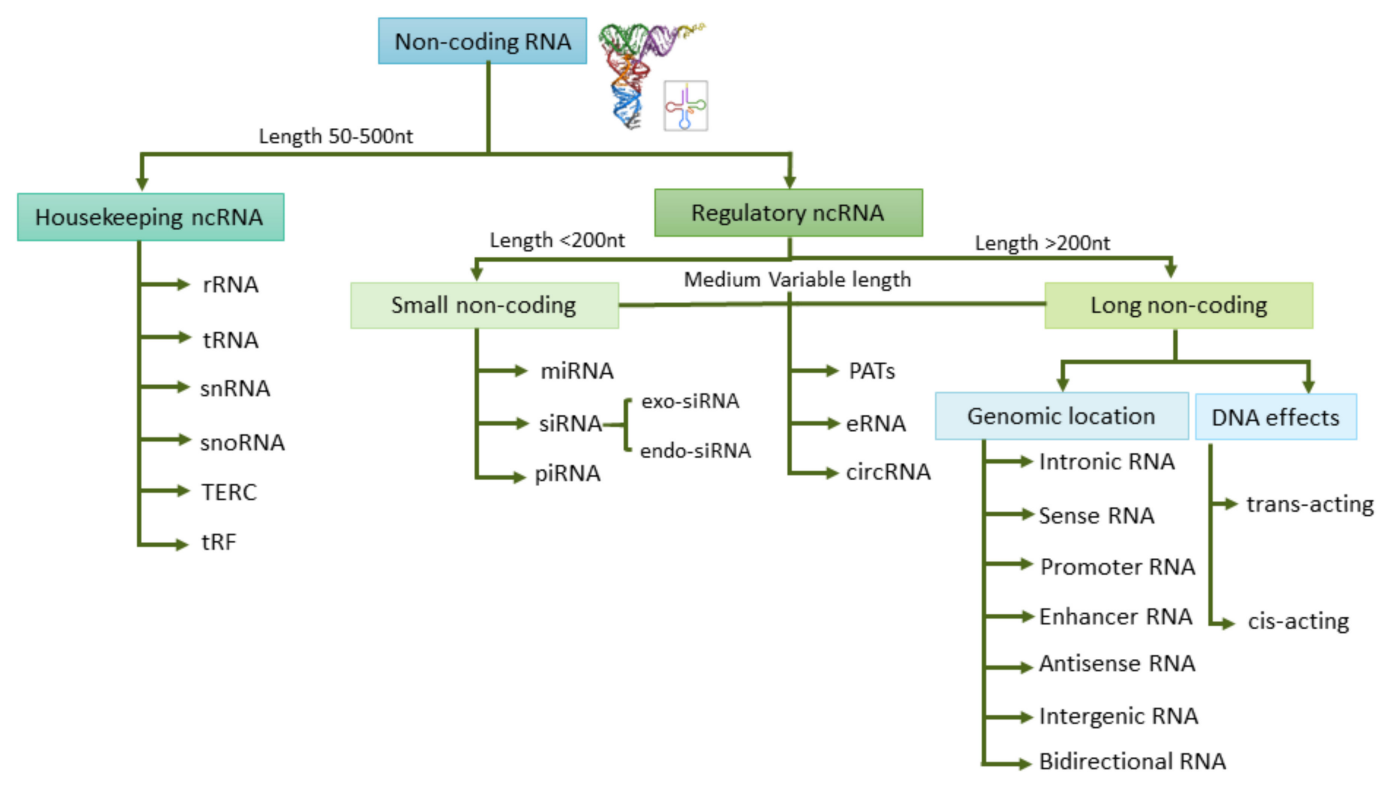

Figure 2. Non-coding (nc)RNAs classification into different groups based on their length and their regulatory roles. Small non coding RNA (sncRNA), long non coding RNA (lncRNA), ribosomal RNA (rRNA), transfer RNA (tRNA), small nuclear (snRNA), small nucleolar (snoRNA), telomerase RNA component (TERC), tRNA-Derived Fragments (tRF) and tRNA halves (tiRNA), microRNA (miRNA), small interfering RNA (siRNA), piwi-interacting RNA (piRNA), promoter-associated transcripts (PATs), enhancer RNA (eRNA), circular RNA (circRNA), and long non-coding RNA (lncRNA).

Changes in histone modification have also been identified in circulation in cancer patients and are another source of epigenetic biomarkers. Nonetheless, due to the complexity of modifications, we will not cover it in our review. Information on this issue has been comprehensively reviewed in a recent study [15].

In this review, we address the most relevant evidence (according to authors' criteria) on epigenetic biomarkers in LB, with special emphasis on tumors with high incidence. We summarize the data about biomarkers currently registered on the market as well as novel emerging candidates.

\section{Types of Biological Fluids for Epigenetic Analysis}

In cancer patients, ctDNA can harbor the same mutational and epigenetic traits as the corresponding tumor [16]. A common and convenient source of LB is blood, but certain tumors are characterized by shedding low amounts of DNA into the blood (i.e., brain, kidney, bladder, prostate, thyroid, or head and neck cancers). In these cases, since their tumor location allows a direct communication with other body fluids, it could be more informative to use alternative samples for the analysis of biomarkers [17].

In head and neck cancer, saliva is an attractive non-invasive sample for screening, diagnosis, and monitoring due to its simple collection and low cost. Salivary nucleic acids have been used, for example, for the identification and validation of DNA methylation 
and miRNAs, demonstrating their utility in several clinical contexts (recently reviewed by [18]). Airway-derived fluids such as bronchial aspirates/lavages and sputum samples, have proven to be accurate tools for the early detection of tumors arising in the respiratory system [7]. Pleural effusion is also a very informative biological sample for biomarker assessment in lung cancer (LuCa) patients. It is well established that the EGFR mutational status can be reliably determined in ctDNA from pleural effusions to predict response to EGFR-tyrosine kinase inhibitors (TKIs) [19]. In contrast, the information on epigenetic biomarkers in pleural fluid is more limited and the clinical value of such biomarkers has to be clearly determined, but recent reports are finding possible association with prognosis [20].

Urine is a bona-fide source of epigenetic biomarkers in the case of genitourinary cancers. DNA hypermethylation has been described as one of the earliest and most frequent aberrations in prostate cancer $(\mathrm{PrCa})$, and the detection of methylation patterns in urinary ctDNA has shown to be clinically meaningful [21]. In bladder cancer (BdCa), promising results from urine-based tests that measure DNA methylation patterns have been described [22]. The potential of miRNAs as biomarkers (individually or in combination) has also been demonstrated for BdCa, showing high sensitivity and specificity [23].

In the case of central nervous system (CNS) tumors and due to the existence of the blood-brain barrier, ctDNA in CSF seems to be a better source than blood [24]. A high concordance between methylation patterns in CSF and matched tumor samples has been reported, indicating the potential use of this biofluid for epigenetic biomarker analysis $[22,25]$.

\section{Technologies for Epigenetic Assays in Liquid Biopsy}

Several techniques have been described for the analysis of epigenetic alterations in CTCs, free circulating nucleic acids and exosomes $[7,26,27]$. According to the number of targets analyzed, these technologies can be divided into (a) single-locus or multiplexed assays; and (b) genome-wide approaches, which are mainly based on microarrays and next-generation sequencing (NGS).

\subsection{DNA Methylation}

The analyses of DNA methylation in ctDNA by single-locus or multiplexed assays are mainly amplification-based methods such as methylation specific PCR (MSP) or digital droplet PCR (ddPCR). MSP is a classical method that encompasses Methylight and MethylQuant assays. MSP detects a small amount of ctDNA among a considerable number of circulating free DNA (cfDNA) [23]. In Methylight assays, the DNA methylation level is analyzed by comparing the fluorescence of specific probes between methylated and unmethylated molecules [28,29]. ddPCR is an ultrasensitive and quantitative method that is useful for the discovery of clinical biomarkers in samples with a low amount of cfDNA. This method is based on a PCR that is conducted in water-oil emulsion droplets where a single DNA molecule can be amplified inside each droplet, thus avoiding the mask effect of the non-target DNA $[26,28]$. Moreover, there are other approaches that combine techniques used for ctDNA studies such as BEAming technology, epityper epigenetic analysis, and methylation sensitive high-resolution technology (MS-HRT). BEAming technology is a method that combines ddPCR and flow cytometry for the analysis of ctDNA $[30,31]$. Epityper epigenetic analysis combines specific enzymatic cleavage with mass spectrometry (MALDI-TOF-MS) [32]. MS-HRT compares the melting profiles of sequences that present differences in their base compositions $[7,26]$.

Regarding genome-wide assays, the methylation analysis of ctDNA can be performed by different techniques such as Infinium DNA methylation EPIC array (EPIC). EPIC is considered the gold standard method for DNA methylation assays due to its costeffectiveness and its ability to examine more than 850,000 CpG sites [33]. 


\subsection{Non-Coding RNAs}

The expression of ncRNAs can be evaluated in LB at targeted-specific level using amplification-based methods such as reverse transcription quantitative PCR (RT-qPCR) and ddPCR. Of note, the use of ddPCR represents a highly sensitive method to quantify the expression of specific transcripts in LB [34-36]. In addition, there are other targeted methods such as peptide nucleic acids (PNAs)-based fluorogenic biosensors [37] and the NanoString nCounter platform that allow for the detection of ncRNA expression levels without the need of previous amplification [38]. In particular, the NanoString nCounter platform is able to analyze a large panel of miRNAs in several types of biological fluids including plasma and urine [39]. Other targeted approaches have also been developed for the detection of miRNAs in CTCs such as in situ hybridization (ISH) with locked-nucleicacid (LNA) probes [40] and methods based on signal amplification in microfluidic droplets for single-cell analysis of multiple miRNAs [41].

The expression of ncRNAs can also be detected in LB at transcriptomic level with the use of NGS (RNA-Seq) or microarrays. Although both technologies allow for the analysis of ncRNA transcripts in LB [42,43], unlike microarrays, RNA-Seq does not require prior knowledge of the target transcripts and shows higher sensitivity for the detection of ncRNAs [42,43]. A summary of the types of technologies, applications, and advantages/disadvantages can be found in Table S1.

\section{Epigenetic Biomarkers in Lung Cancer}

Lung cancer ( $\mathrm{LuCa}$ ) is currently the second most commonly diagnosed cancer and the leading cause of cancer-related deaths worldwide among women and men. Globally, there were an estimated 2.2 million lung cancer cases and 1.8 million deaths in 2018, accounting for approximately a third of all cancer cases and deaths [44]. LuCa is one of the most aggressive tumor types, with a 5-year survival rate that varies globally but remains consistently low, not exceeding 19\% [45]. There are two main types of LuCa: non-small cell lung cancer (NSCLC, $\sim 85 \%$ cases) and small cell lung cancer (SCLC, $15 \%$ cases). NSCLC is subdivided in three main histological subtypes: adenocarcinoma (LUAD) ( 40\% of NSCLC cases), squamous cell carcinoma (LUSC) ( $\sim 30 \%$ of NSCLC cases), and large-cell carcinoma ( $10-15 \%$ of NSCLC cases).

Despite breakthroughs in LuCa treatments in the last few decades, which have gradually improved patient's outcome, the mortality rate is still considerably behind that observed for other prevalent types such as breast or colon cancer. A major factor is the late diagnosis and, consequently, its late-stage presentation. In recent years, increased interest has been directed toward the use of imaging techniques and biomarkers for screening and early detection. In randomized trials, the use of low-dose computed tomography (LDCT) in populations at risk has shown a significant reduction in lung cancer mortality [46]. However, there are still several questions regarding LDCT, which require further research. Examples are clarification of cost-effectiveness in different populations; characterization of detected nodules with indeterminate risk level; the small but significant percentage of false-positive cases and the potential harms associated with unnecessary invasive interventions (biopsies or even surgeries) of these cases; and the potential tools to optimize risk assessment, to recommend for screening only those individuals with higher risk, not only based on age and smoking exposure [47]. It is then possible that the use of LB-based molecular biomarkers in screening programs might help LDCTs in identifying NSCLC. Biological fluids that can be used as a source for biomarkers in LuCa include blood, bronchial aspirates (BAS), bronchial lavages (BAL), sputum or pleural effusions, for analysis of ctDNA, exosomes, and CTCs.

\subsection{DNA Methylation}

Among DNA methylation biomarkers in LuCa diagnosis, SHOX2 hypermethylation is clearly the best studied epigenetic alteration. SHOX2 hypermethylation was first described by Schmidt et al. using bronchial fluid aspirates during bronchoscopy, showing $68 \%$ 
sensitivity and $95 \%$ specificity [48]. Other studies [49-51] have later validated the diagnostic potential of SHOX2 methylation status in plasma and pleural effusions. The EpiProLung ${ }^{\circledR}$ assay is the only commercial test specifically designed for LuCa diagnosis. This test is based on a PCR assay that analyzes methylation of SHOX2 and PTGER4 in blood, with a sensitivity of $78 \%$ and specificity of $96 \%$, and an area under the ROC curve (AUC) of 0.73 . This gene combination has also been tested in lavage fluid samples.

Other genes have been found to be differentially methylated in plasma samples when comparing LuCa patients and healthy controls including DCLK1 (49\% sensitivity and 91\% specificity) [52], SEPT9 (44\% sensitivity and 92\% specificity) [53], RASSF1A and RARB2 ( $87 \%$ sensitivity and $75 \%$ specificity) [54]. Hulbert et al. demonstrated that analyzing the DNA methylation status of different genes such as TAC1 (86\% sensitivity and 75\% specificity), HOXA7 (63\% sensitivity and $92 \%$ specificity) and SOX17 (84\% sensitivity and $88 \%$ specificity) allowed for the detection of LuCa in sputum samples with a global sensitivity of $98 \%$ and specificity of $71 \%[55,56]$. Interestingly this group has also published that methylation analysis of CDO1, TAC1, HOXA9, and SOX17 in urine (as well as in plasma) can be useful as an adjunct to LDCT screening [57]. Recently, our group has developed an epigenetic model identified through epigenomic analysis by which the DNA methylation status of four genes (BCAT1, CDO1, TRIM58, and ZNF177) in BAS/BAL/sputum samples was able to discriminate between NSCLC patients (even at early stages) and controls ( $82 \%$ sensitivity and $76 \%$ specificity, AUC, $\sim 0.9)[55,58]$. We have also described that TMPRSS4 hypomethylation can be used as a diagnostic tool in early stages, with an AUC of 0.72 (52\% sensitivity and $91 \%$ specificity) for BAL and 0.73 (90\% sensitivity and $65 \%$ specificity) for plasma [59].

Through genome-wide DNA methylation assays, Hsu et al. detected a multiple epigenetic panel in tumor samples by studying the methylation status of genes $C D H 13$, $B L U$, FHIT, RASSF1A, and RARB, whose diagnostic potential was also validated in plasma samples with a sensitivity of $73 \%$ and a specificity of $82 \%$ [60]. Similarly, Ostrow et al. validated in plasma a group of four genes (DCC, Kif1a, NISCH, RARB) that was previously found in tumors, which discriminated between LuCa patients and tumor-free individuals, with a sensitivity of $73 \%$ and specificity of $71 \%$ [61]. In addition, Ooki et al. described a serum-based gene signature, previously identified in tumors from TCGA (MARCH11, HOXA9, CDO1, UNCX, PTGDR, and AJAP1) that was able to differentiate stage I NSCLC patients from the controls, with $72.1 \%$ sensitivity and $71.4 \%$ specificity [62].

Unlike for diagnosis, only a few studies have described the association between DNA methylation status and outcome or response to drugs using ctDNA [63,64]. Hypermethylation of SHP1P2 in plasma was associated with reduced progression-free survival (PFS) in advanced NSCLC [65]. DNA methylation of the gene panel SOX17, BMRS1, and DCLK1 in plasma had a negative impact on survival $[52,66,67]$, whereas SFN methylation in serum samples was associated with improved survival [68]. Salazar et al. described that patients with unmethylated CHFR had an improved survival when treated with second-line EGFR TKIs [69]. Additionally, increased plasma ctDNA methylation levels of RASSF1A and APC within $24 \mathrm{~h}$ after chemotherapy administration was found to be associated with good response to cisplatin [70]. In addition, using plasma samples, prolonged survival has been observed in patients with low SHOX2 promoter methylation after chemotherapy/radiotherapy [48].

\section{2. $n c R N A s$}

ncRNAs are also becoming a valuable tool for the early detection of LuCa. miRNAs, the most widely studied type of ncRNA, provide promising biomarkers for the diagnosis and prognosis of LuCa [71]. For instance, miR-1285 was significantly decreased while miR324-3p was significantly increased in plasma of stage I LUSC patients in contrast to healthy donors (AUC 0.85 and 0.79, respectively) [72]. Chen et al. described 10 miRNAs (miR-20a, miR-222, miR-221, miR-320, miR-152, miR-145, miR-223, miR-199a-5p, miR-24, miR-25) able to discriminate NSCLC patients from healthy controls, with high sensitivity (92.5\%) 
and specificity (90\%) rates (AUC 0.97) [73]. miR-21, the most commonly studied miRNA in $\mathrm{LuCa}$, has been found consistently upregulated in both serum and plasma samples and may serve as a diagnostic biomarker of early-stage NSCLC. Yu et al. reported that miR-21 was suitable for diagnosis, with $69 \%$ sensitivity and $71.9 \%$ specificity [74]. A multicenter study was performed with a total of 3102 participants to investigate the potential use of circulating miRNAs as diagnostic biomarkers in LuCa. Results reported that a 14-miRNA signature might be useful to discriminate patients with early-stage lung cancer (stage I or II) from healthy individuals. Specifically, miR-374b-5p differentiated patients with early-stage LuCa from those without cancer, with an AUC of 0.83 [75]. Some groups have studied miRNA precursors as diagnostic biomarkers in LuCa. Powrózek et al. reported that miRNA-944 precursors distinguished SCC from ADC with 78.6\% sensitivity and $91.7 \%$ specificity (AUC $=0.77$ ), and pri-miRNA-3662 discriminated SCC from ADC with $57.1 \%$ sensitivity and $90 \%$ specificity $($ AUC $=0.845)$. Both markers allowed to distinguish stage I-IIIA NSCLC from healthy individuals with $75.7 \%$ sensitivity and $82.3 \%$ specificity $(\mathrm{AUC}=0.898)[76]$.

Some ncRNAs have also been proposed as prognostic biomarkers for LuCa. A recent study using a cohort of 182 patients with resected early-stage NSCLC reported that, among 84 circulating microRNAs, only miR-126-3p had an independent prognostic value in SCC patients [77]. Moreover, Yanaihara et al. showed that high expression of precursor has-mir155 could be an independent poor prognosis biomarker in ADC patients [78]. Increasing evidence shows that lncRNA can also act as biomarkers for prognosis. Xie et al. reported in a cohort of 460 patients that low serum levels of SOX2OT and ANRIL were associated with higher overall survival (OS) rate. Multivariate analysis revealed that SOX2OT could be an independent prognostic factor for NSCLC [79]. Yung-Hung Luo et al. studied the correlation between clinicopathological characteristics and circRNAs using plasma from a cohort of $231 \mathrm{LuCa}$ patients (65 had stage I-II and 166 stage III-IV) and 41 healthy donors. They reported that higher levels of circ_0000190 were correlated with larger primary tumor size, advanced stage, extrathoracic metastasis, and poor survival [80].

miR-21 has been identified as a key miRNA in the regulation of acquired resistance to EGFR-TKIs in NSCLC, and high serum levels of this miRNA have been found to be significantly increased at the time of EGFR-TKI progression when compared to those observed before treatment [81]. Wang et al. also demonstrated that patients who were resistant to EGFR-TKIs had higher levels of circulating miR-21, miR-27a, and miR-218 than patients who were sensitive [82]. Jinshuo Fan et al. found that NSCLC patients who were responsive to ICIs (immune checkpoint inhibitors) had increased levels of a signature composed of miR-27a, miR-28, miR-34a, miR-93, miR-106b, miR-138-5p, miR-181a, miR193a-3p, miR-200, and miR-424 compared to non-responders. Moreover, patients with high levels of this signature showed improved PFS and OS than those where levels were low [83]. Recently, expression of circ_0000190 has been found to be correlated with PD-L1 expression and response to immunotherapy in NSCLC [80].

\section{Epigenetic Biomarkers in Genitourinary Cancers}

The most prevalent tumors of the genitourinary (GU) tract are prostate cancer $(\mathrm{PrCa})$, bladder cancer (BdCa), and renal cell carcinoma (RCC) [84]. PrCa is the second most commonly diagnosed cancer and the sixth leading cause of cancer death among men worldwide [85]. PrCa diagnosis has not evolved significantly since the 1980s, when blood levels of prostate-specific antigen (PSA) were first introduced as a follow-up marker for recurrent tumors, and, subsequently, for early detection in combination with digital rectal examination (DRE) [77,86]. PSA for PrCa screening has low positive predictive value $(\sim 30 \%)$, potentially driving to over-diagnosis and over-treatment. This highlights the need of more accurate biomarkers that are alternative or complementary to PSA for screening and diagnosis [87]. In the case of $\mathrm{BdCa}$, there was an estimated number of 550,000 cases and 200,000 deaths (2.1\% of all cancer deaths) in 2018 [88]. The 5-year survival rates ( 77\%) have remained mostly unchanged since the 90s [89]. Although less frequent, RCC accounts 
for $\sim 2 \%$ of all diagnosed cancers, but its incidence has more than doubled over the past fifty years, being the tenth most common neoplasm in men [84,90]. RCC diagnosis is mostly an accidental finding and represents $1.8 \%$ of all cancer deaths worldwide [90]. The therapeutic options for RCC have increased tremendously in recent years, but biomarkers of response to these drugs are still lacking.

\subsection{DNA Methylation}

A common trait of GU tumors is the possibility of using urine as a biological fluid for the analysis of CTCs and ctDNA [7]. Commercial epigenetic-based kits for the detection of $\mathrm{PrCa}$ and Bdca in both urine and blood samples are currently available [7]. Unfortunately, epigenetic markers in liquid biopsies from RCC patients are underdeveloped, as this is one of the tumor types with less ctDNA shedding into biological fluids [91-93]. Among DNA methylation biomarkers in GU cancers, GSTP1 hypermethylation is by far the most frequently described epigenetic alteration, especially in PrCa patients [94]. Many authors have described its utility for PrCa detection $[95,96]$ showing much higher specificity $(\sim 90 \%)$ than PSA ( 30\%), although sensitivity was similar for both PSA levels and GSTP1 methylation $[87,95]$. Matched assessment of ctDNA GSTP1 in urine and plasma samples revealed that urinary analysis outperforms plasma for diagnostic purposes [96,97]. It is worth mentioning that the DNA methylation analysis of multi-gene panels in serum including GSTP1, RASSF1A, and RARB have increased the diagnostic coverage of GSTP1 alone [98] for PrCa. Similar strategies have also been used for BdCa detection (with 100\% sensitivity) in a multi-gene panel that assessed CDKN2A, ARF, MGMT, and GSTP1 [86]. In the case of RCC, methylation analysis of serum cfDNA using GSTP1 alone or in combination with either APC, p14ARF, p16, RARB, RASSF1, TIMP3, or PTGS2 has been shown to provide a high accuracy of detection (AUC ranging from 0.73 to 0.75 ; $95 \%$ IC $0.50-0.84$ ) [99]. Independently, Hoque et al. measured GSTP1 together with CDH1, APC, MGMT, RASSF1A, $p 16, R A R B 2$, and $A R F$ methylation for RCC detection using urine and plasma samples, showing that at least one gene was hypermethylated in $88 \%$ and $67 \%$ of the patient's urine sediments and plasma, respectively. [100].

Other gene panels that do not include GSTP1 are also under study for $\mathrm{PrCa}$ and $\mathrm{BdCa}$ detection. Analysis of MCAM, ERalpha, and ERbeta showed $75 \%$ sensitivity and $70 \%$ specificity for early PrCa detection [101]. Similarly, ST6GALNAC3, ZNF660, CCDC181, and HAPLN3 detected PrCa patients with up to $100 \%$ specificity and $67 \%$ sensitivity [102]. With respect to $\mathrm{BdCa}$, methylation status of several genes are reliable alone or in combination using ctDNA in serum: CDH13 [103], PCDH10 [104], and PCDH17 [105]. Additionally, dual combinations such as PCDH17 and POU4F2 (93.96\% sensitivity, 90\% specificity) [106] or NID2 and TWIST1 (90\% sensitivity and 93\% specificity) [107] have been proven to be accurate for the detection of BdCa patients using urine samples [108]. Several commercial tests that include epigenetic and non-epigenetic biomarkers are now available for the diagnosis of BdCa using urine or blood (AssureMDx ${ }^{\circledR}$, Bladder CARE ${ }^{\circledR}$, Bladder EPICHECK ${ }^{\circledR}$ ). In RCC, a panel of genes that act as Wnt antagonists can serve as biomarkers for diagnosis, staging, and prognosis using serum ctDNA [109]. Notably, Vitale Nuzzo P et al. used cell-free methylated DNA immunoprecipitation and high-throughput sequencing (cfMeDIP-seq) as a highly sensitive assay capable of detecting and discriminating earlystage RCC from other tumor types and healthy controls in plasma (AUC 0.9) and urine (AUC 0.86) [110]. Taking into account the different studies related to diagnosis in $\mathrm{PrCa}$, $\mathrm{BdCa}$, and RCC, hypermethylation of RASSF1A, APC, RARB2, and ARF [111,112] seem to be the most consolidated biomarkers to use in plasma, serum, and/or urine.

The potential of DNA methylation analysis in LB related to progression and therapy response is an area of intense study. Sunami et al. reported that methylation of GSTP1, RASSF1A, and RARB2 associated with PrCa's Gleason score and serum PSA; in addition, GSTP1 and RARB2 were associated with the disease's advanced stage [98]. Likewise, it has recently been shown that hypermethylation of $A P C, G S T P 1$, and RARB2 in urine sediments correlated with shorter RFS and higher PrCa grade [113]. Additionally, in the case of 
urine, dual assessment of GSTP1 and APC discriminates between low-risk and aggressive PrCa [114]. Interestingly, Zhao et al. showed that monitoring GSTP1, APC, CRIP3, and HOXD8 methylation was useful for noninvasive prediction of PrCa aggressive disease in patients on active surveillance [115]. Indeed, the same group of authors developed a PrCa urinary epigenetic assay $\left(\right.$ ProCUrE $\left.^{\circledR}\right)$ with diagnostic and prognostic purposes based on the optimized measurement of GSTP1 and HOXD3 gene methylation [116]. In the case of $\mathrm{BdCa}, \mathrm{PCDH} 10$ and PCDH17 hypermethylation were independent predictors of cancer survival and correlated with higher stage and grade [104,105], as described for NID2 and TWIST1, which were able to discriminate between different patient's BdCa grades [108]. Finally, a multigene panel useful for BdCa recurrence surveillance has been developed, which included EOMES, HOXA9, POU4F2, TWIST1, VIM, and ZNF154 [117]. A number of registered clinical trials (in some cases using commercial tests) for screening or recurrence purposes have been initiated in the case of $\mathrm{PrCa}$ and BdCa (https:/ / www.clinicaltrials.gov / (accessed on 30 December 2020)) (Table S2).

\section{2. ncRNAs}

In terms of ncRNA, several studies have shown their possible role as biomarkers in LB. Yu et al. recently designed a 4-lncRNA panel of urinary biomarkers (UCA1-201, HOTAIR, HYMA1, and MALAT1) for the diagnosis of non-muscle invasive bladder cancer (NMIBC) [118]. This signature confirmed the presence of tumor in a validation cohort of 140 NMIBC patients. A different study identified a 7-miRNA panel providing high diagnostic accuracy in BdCa using urine samples (miR-7-5p, miR-22-3p, miR-29a-3p, miR126-5p, miR-200a-3p, miR-375, and miR-423-5p) [119]. Urquidi et al. described a sensitivity of $87 \%$ and a specificity of $100 \%$ using a different 25-miRNA urine signature [120]. An interesting approach integrated the expression of the mRNA HYAL1 together with two miRNAs (miR-96 and miR-210) and one lncRNA (UCA1) in an urine diagnostic panel that achieved a sensitivity of $100 \%$ and a specificity of $89.5 \%$ [121]. Interestingly, the lncRNA UCA1 increases cisplatin resistance in BdCa [122]. In the case of PrCa, ncRNA profiling could be a powerful tool to complement PSA screening. A recent study found a robust diagnostic model in serum using two different miRNAs (miR-17-3p and miR1185-2-3p) with an associated $90 \%$ sensitivity and $90 \%$ specificity [123]. Serum detection of PSA in combination with miR-103a-3p and let-7a-5p detected PrCa cases better than PSA alone [124]. Serum miR-106b, miR-141-3p, miR-21, and miR-375 have also been combined in a panel with AUC of 0.86 [125].

\section{Epigenetic Biomarkers in Breast Cancer}

Breast cancer $(\mathrm{BrCa})$ is the most common neoplasm diagnosed in females worldwide, with an incidence of $11.7 \%$ of all women cancer cases [44]. Screening based on imaging is key for the early detection and better prognosis of this disease, with mammograms being the most frequent technique recommended. However, the breast cancer nodules do not always exhibit pathognomonic characteristics, which can prevent the radiologist from performing a biopsy, or in other cases, generate false positives. Other limitations of this technique include the possible cumulative radiation exposure and over-diagnosis [126-128]. For these reasons among others, the search for potential non-invasive biomarkers in $\mathrm{BrCa}$ is needed.

\subsection{DNA Methylation}

Multiple studies have explored epigenetic alterations in ctDNA from BrCa patients that could serve for diagnosis, prognosis, classification of BrCa subtypes, and prediction of response to therapies. One of the most frequently studied markers has been the hypermethylation of RASSF1A [129-133], which discriminates between healthy individuals and BrCa patients and acts as a poor prognosis indicator [134]. Moreover, this aberration predicts the response to tamoxifen or neoadjuvant chemotherapy [135]. Other methylated targets found in plasma from $\mathrm{BrCa}$ patients with a diagnostic value encompass 
SOX17, CST6, APC, DAK-K, MASPIN, HIC-1, HIN-1, RARB, RARbeta2, GSTP1, BRCA1, and KIF1A [32,129-132,136-139]. Among these targets, the hypermethylation of RASSF1A, $B R C A 1, R A R B$, and $R A R B 2$, in estrogen receptor+ $(\mathrm{ER}+)$ and progesterone receptor $(\mathrm{PR}+)$ breast tumors and plasmas, were validated as indicators of poor prognosis in at least two independent studies [140]. Furthermore, Fujita et al. showed that the simultaneous detection of RASSF1A, RARB, and GSTP1 methylation (93\% specificity) was strongly correlated with poor outcome [141]. SOX17 methylation is another independent prognostic factor (HR: 4.737; 95\% CI: 2.088-10.747) and its methylation status in ctDNA from plasma samples was found to correlate (70.9\% concordance) with that observed in CTCs from matched BrCa patients [142,143]. PITX2 hypermethylation in plasma has also been reported as another indicator of poor OS (HR: 3.4; 95\% CI: 1.2-9.8) [144]. Interestingly, PITX2 hypermethylation also predicted the response to anthracycline-based therapy [145].

In relation to ER status, Martinez-Galan et al. demonstrated methylation of $E R$ and ESR1 promoters in plasma from ER- patients [146]. In contrast, PTPRO methylation was found as a prognostic factor (HR: 3.66; 95\% CI: 1.371-9.784) in ER+ positive BrCa patients but not in ER - [141]. Some gene panels have been designed to simultaneously analyze several gene methylation patterns in $\mathrm{BrCa}$ serum/plasma. For instance, Visvanathan et al. developed a panel of 10 genes including RASSF1A, whose methylation index predicted worse PFS (HR: 1.79; CI 95\%: 1.23-2.60, and OS (HR: 1.75; 95\% CI: 1.21-2.54) in metastatic BrCa patients [147]. Although evaluation of the methylation status in these genes is promising, there is currently only one commercial kit available specifically for $\mathrm{BrCa}$, which tests for PITX2 methylation in paraffin samples (Therascreen ${ }^{\circledR}$, Qiagen, Frankfurt, Germany) [134].

\section{2. $n c R N A s$}

The potential value of ncRNAs as BrCa biomarkers in serum or plasma (either in exosomes or as cfRNA) has also been reported. Exosomal miR-21 has been widely shown to be a diagnostic biomarker, with sensitivity and specificity in pooled studies of $\sim 75 \%$ and $\sim 85 \%$, respectively, and an AUC of 0.93 [148]. There are hundreds of studies proposing miRNAs as diagnostic and prognostic biomarkers in $\mathrm{BrCa}$, but they need validation. We summarize here some recent relevant publications. In BrCa plasma samples, combination of four miRNAs (miR-1246, miR-206, miR-24, miR-373) distinguished BrCa from healthy individuals with $98 \%$ sensitivity, $96 \%$ specificity, and accuracy of $97 \%$ [149]. A panel composed of exosomal miR-142-5p, miR-320a, and miR-4433b-5p isolated from a BrCa patient's serum differentiated patients from their control counterparts with $93.33 \%$ sensitivity, $68.75 \%$ specificity, and AUC of 0.83 [135]. Furthermore, the combination of miR-142-5p and miR-320a discriminated luminal A subtype from healthy donors with $100 \%$ sensitivity, 93.80\% specificity, and AUC of 0.94. Interestingly, decreased expression of miR-142-5p and miR-150-5p were significantly associated with more advanced tumor grades (grade III), while the decreased expression of miR-142-5p and miR-320a was associated with a larger tumor size [135]. Additionally, circulating miR-30b-5b has been recently reported to act as a BrCa prognostic factor [150].

Serum miRNA profiles may be useful for the diagnosis of axillary lymph node metastasis before surgery in a less-invasive manner than sentinel lymph node biopsy. A model that includes a combination of two miRNAs (miR-629-3p and miR-4710) and three clinicopathological factors ( $\mathrm{T}$ stage, lymphovascular invasion, and ultrasound findings) showed an optimal diagnostic potential, with $88 \%$ sensitivity, $69 \%$ specificity, and accuracy of 0.86 [151].

There are also data that correlate ncRNA levels in serum to treatment response. For example, a set of exosomal miRNAs (miR-185, miR-4283, miR-5008 and miR-3613, miR1302, miR-4715, and miR-3144) that target pathways of immune maturation predicted poor neoadjuvant chemotherapy response prior to surgery [152]. Similarly, lncH19 levels in the plasma of BrCa patients have also been reported to predict response to neoadjuvant chemotherapy [153]. 


\section{Epigenetic Biomarkers in Colorectal Cancer}

Colorectal cancer (CRC) is the third most common cancer worldwide. This tumor represents approximately $10 \%$ of all diagnosed cancer cases, with approximately 1.8 million new cases estimated in 2018. It is important to note that CRC is responsible for approximately $9 \%$ of all cancer deaths, being the second leading cause of cancer mortality [154]. In $\mathrm{CRC}$, screening strategies have been shown to be effective to detect early CRC and precancerous lesions, and to reduce its morbidity and mortality. Among the detection strategies, the fecal immunochemical test (FIT) represents a non-invasive and cost-effective assay for detecting the presence of fecal hemoglobin. This is currently the most commonly used method for CRC screening, with an overall sensitivity and specificity for detection of $79 \%$ and $94 \%$, respectively. However, the ability of this assay to detect advanced precancerous lesions is limited, showing $24 \%$ sensitivity and $95 \%$ specificity [155]. After a positive result for FIT, colonoscopy is the gold standard diagnostic technique for CRC detection. However, it is an invasive method that needs bowel preparation and sedation, presenting certain risk of complications for the patients [156]. In this context, the use of epigenetic biomarkers such as DNA methylation in stool samples might provide a non-invasive and the most cost-effective approach in population-based screening for both CRC and precancerous lesions [157]. Thus, for example, the simultaneous methylation analysis of SEPT9 and SDC2 (ColoDefense ${ }^{\circledR}$ test) in stool samples was able to obtain a sensitivity of $66.7 \%$ for advanced adenoma (AA) and $92.3 \%$ for CRC, with a specificity of $93.2 \%$ [158].

\subsection{DNA Methylation}

Among the most frequently studied epigenetic biomarkers in ctDNA for CRC, the methylation of SEPTIN9 (SEPT9) stands out for screening and early detection $[144,159,160]$. The EpiproColon ${ }^{\circledR}$ test was the first commercially available FDA-approved test for the detection of SEPT9 methylation in plasma by real-time PCR [161,162]. In addition to blood samples, methylation of this gene has also been analyzed in stool, showing a $35.9 \%$ improvement in detecting pre-tumoral stages (AA) and $7.9 \%$ in identifying early CRC tumors, in comparison with the plasma test [163]. The use of ColoDefense ${ }^{\circledR}$ in blood enabled the detection of AA and CRC, with an overall sensitivity of $88.9 \%$ and a specificity of $92.8 \%$ [164]. Similarly, other studies have proposed the analysis of the methylation of several genes in plasma as circulating epigenetic biomarkers able to discriminate between healthy controls and patients with AA or CRC $[165,166]$. In addition, approaches based on methylation microarrays [33] and NGS [167] have been used to identify epigenetic biomarkers in ctDNA for cancer detection.

Regarding prognosis, hypermethylation of the P16 promoter in ctDNA has been associated with poor OS [168]. Additionally, hypermethylation of HPP1 and HLTF indicates a poor prognosis and high mortality [169], and hypermethylation of RARB and RASSF1A was associated with the aggressiveness of the disease [170] in patients with CRC. Methylation of ctDNA can also be used to monitor tumor burden and evaluate the therapeutic response of patients [171,172], correlating better than classical biomarkers such as carcinoembryonic antigen (CEA) and carbohydrate antigen (CA)-19-9. For example, the analysis of the methylation status of the 2-gene panel BCAT1/IKZF1 in plasma showed higher sensitivity for detecting CRC recurrence than CEA, with an odds ratio of 14.4 (95\% CI: 5-39) and 6.9 (95\% CI: 2-22), respectively [173]. Similarly, the plasma methylation of SEPT9, $D C C, B O L L$, and SRFP2 showed stronger correlation with tumor burden than CEA and CA-19-9 [172].

\section{2. $n c R N A s$}

Circulating levels of ncRNAs have also shown utility as biomarkers in the management of CRC. Circulating miR-21 levels in blood and saliva allow for the detection of CRC $[174,175]$. In addition, miRNA signatures evaluated in fluids can be useful for discriminating between healthy controls, patients with adenomas, and patients with CRC with high sensitivity and specificity. In particular, the plasma levels of miR-601 and miR-760 
showed an AUC of 0.68 with $72.1 \%$ sensitivity and $62.1 \%$ specificity, which can discriminate between AA and healthy donors. In addition, this panel of miRNAs was able to differentiate CRC from the control samples with an AUC of 0.79 , a sensitivity of $83.3 \%$, and a specificity of $69.1 \%$ [176]. Another study has recently identified a signature of six miRNAs (miRNA19a, miRNA19b, miRNA15b, miRNA29a, miRNA335, and miRNA18a) with an AUC of 0.92 , a sensitivity of $85 \%$, and a specificity of $90 \%$ that is able to detect CRC and AA in comparison to healthy individuals [157]. Regarding prognosis, high levels of circulating miR-210 and miR-141 are associated with shorter survival [165,177], while high levels of miR-23b are associated with longer survival [178]. Besides, levels of different miRNAs in blood may be useful for the early detection of recurrence [179] and evaluation of therapy response in CRC patients [180]. High plasma levels of the lncRNA HOTAIR have shown utility for the detection of CRC and association with a worse prognosis and higher mortality [181]. Of note, other studies have analyzed different combinations of circulating lncRNAs as diagnostic biomarkers, which were useful for the detection of adenomas and CRC $[166,182,183]$.

\section{Epigenetic Biomarkers in Other Tumor Types and Multi-Cancer Tests}

In addition to common tumor types, epigenetic alterations may also be detected in LB from other less frequent malignancies, showing clinical utility as tumor biomarkers. In cutaneous melanoma, where the use of circulating epigenetic biomarkers has been proposed as a non-invasive tool for tumor detection, promoter hypermethylation of RASSF1A has been described in plasma samples as a diagnostic indicator, with the ability of discriminating between melanoma patients and healthy individuals, showing a good diagnostic accuracy with an AUC of 0.90 [184]. Besides, the detection of hypermethylated RASSF1A in serum before treatment was able to predict the prognosis and clinical response to drugs in advanced melanoma patients [185]. In a recent pilot study using NGS and machine learning, Bustos et al. were able to identify a circulating miRNA signature (miR-4649-3p, miR-615-3p, and miR-1234-3p) associated with the response to ICIs in advanced melanoma patients, suggesting that circulating miRNAs could enable real-time monitoring of patients receiving this type of treatment [167]. The plasmatic levels of other ncRNAs such as lncRNAs (IGF2AS, anti-Peg11, MEG3, Zeb2NAT) were also found to be associated with prognosis and therapy response in $B R A F$-mutant advanced melanoma patients treated with the BRAF inhibitor vemurafenib [186]. Similar to melanoma, the blood-based analysis of DNA methylation and ncRNAs has shown utility as circulating epigenetic biomarkers for other tumors including pancreatic cancer [187], ovarian and endometrial carcinomas [188,189], and brain tumors [190], among others.

In brain tumors such as glioblastoma, promoter hypermethylation of several genes (MGMT, p16INK4a, TIMP-3, and THBS1) has been detected at high frequencies in serum and CSF. In glioblastoma, hypermethylation of MGMT is associated with response to temozolamide [191]. The methylation status of MGMT and THBS1 in CSF was also able to independently predict PFS of glioblastoma patients [22]. Similar to methylation, the circulating microRNA profiling of CSF has also been proposed as a good approach for the non-invasive detection (miR-30e, miR-140, let-7b, mR-10a, and miR-21-3p) and prognosis (miR-10b and miR-196b) of glioblastoma patients [192]. In other tumor types such as oral cancer, the analysis of epigenetic biomarkers in saliva has been explored. In this sense, the promoter hypermethylation of different types of genes (e.g., RASSF1A, p16 INK4a, TIMP3, and PCQAP/MED15) and the expression levels of miRNAs in saliva have been detected in association with oral tumors $[18,193]$. Thus, the study of epigenetic biomarkers in saliva has been proposed as an easily accessible LB sample for oral cancer detection.

The recent application of NGS has allowed for the development of sensitive epigenetic assays for the detection of both common and less-frequent tumors. Thus, using NGS and machine learning, Liu et al., in a very large clinical trial including individuals with ( $n=2482)$ and without cancer $(n=4207)$, recently developed a classifier based on the methylation of cfDNA, assessing $>100,000$ methylation sites in plasma for the sensitive 
detection of more than 50 tumor types [169]. This multi-cancer approach was useful across all stages of the disease, and also for the identification of the tissue of origin with high accuracy, which could be relevant for the treatment and follow-up of the patients. The assay is going to be commercialized by the Biotech Company GRAIL. PanSeer ${ }^{\circledR}$ is an NGS-based assay that is able to detect cancer in asymptomatic individuals, years before standard diagnosis [194].

Table 1 shows a list of the top methylated genes and ncRNAs identified in LB from cancer patients, with an emerging role as biomarkers. This list has been established based on the number of studies and robustness of the genes/ncRNAs published and/or inclusion in commercial tests.

Table 1. Top methylated genes/signatures and ncRNAs identified in liquid biopsies from cancer patients, with an emerging role as biomarkers. BAL: bronchoalveolar lavage; BAS: bronchoalveolar aspirate; CSF: cerebrospinal fluid.

\begin{tabular}{|c|c|c|c|c|}
\hline Epigenetic Alteration & Gene Name(s)/Epigenetic Kit & Type of Liquid Biopsy & Intended Use & Reference \\
\hline \multicolumn{5}{|c|}{ LUNG CANCER } \\
\hline \multirow{3}{*}{ DNA methylation } & \multirow{3}{*}{$\begin{array}{c}\text {-SHOX2/PTGER4 (EpiProLung) } \\
\text {-Gene sets including RASFF1A and other genes } \\
\text {-BCAT1/CDO1/TRIM58/ZNF177 }\end{array}$} & Blood & Diagnosis & [66] \\
\hline & & BAL/sputum & Diagnosis & {$[54-57,62]$} \\
\hline & & BAS/BAL/sputum & Diagnosis & [58] \\
\hline \multirow{2}{*}{ ncRNAs } & $-\mathrm{miR} 21$ & Blood & Diagnosis & [74] \\
\hline & -Several miRNA signatures & Blood & Diagnosis & {$[72,73]$} \\
\hline \multicolumn{5}{|c|}{ GENITOURINARY CANCERS } \\
\hline \multirow{3}{*}{ DNA methylation } & \multirow{3}{*}{$\begin{array}{c}\text {-Gene sets including GSTP1, RASFF1A, APC, ARF } \\
\text { and RARB2 } \\
\text {-Several gene sets (AssureMDx }{ }^{\circledR}, \text { Bladder CARE }^{\circledR} \text {, } \\
\text { Bladder EPICHECK }{ }^{\circledR} \text { ) } \\
\text {-GSTP1 and HOXD3 (ProCUrE, Prostate cancer) }\end{array}$} & Urine, blood & Diagnosis & {$[94,96]$} \\
\hline & & Urine, blood & Diagnosis & {$[103,108]$} \\
\hline & & Urine & Diagnosis & [116] \\
\hline ncRNAs & -Several miRNA and lncRNA signatures & Blood & Diagnosis & [118-120] \\
\hline \multicolumn{5}{|c|}{ BREAST CANCER } \\
\hline DNA methylation & $\begin{array}{c}\text {-Gene sets including GSTP1, RASFF1A, BRCA1 and } \\
\text { RARB2 } \\
\text {-PITX2 }\end{array}$ & $\begin{array}{l}\text { Blood } \\
\text { Blood }\end{array}$ & $\begin{array}{l}\text { Diagnosis } \\
\text { Prognosis/response }\end{array}$ & $\begin{array}{c}{[129-133,136-139]} \\
{[144,145]}\end{array}$ \\
\hline \multirow{2}{*}{ ncRNAs } & \multirow{2}{*}{$\begin{array}{c}- \text { miR21 } \\
\text {-Several miRNA signatures }\end{array}$} & Blood & Diagnosis & [148] \\
\hline & & Blood & Diagnosis & {$[149,151]$} \\
\hline \multicolumn{5}{|c|}{ COLORECTAL CANCER } \\
\hline \multirow{4}{*}{ DNA methylation } & -SEPT9 (EpiProColon ${ }^{\circledR}$ ) & Stool, blood, & Diagnosis & {$[161,162]$} \\
\hline & -SEPT9 and SDC2 (ColoDefense $\left.{ }^{\circledR}\right)$ & Stool, blood & Diagnosis & {$[158]$} \\
\hline & -p16, RASFF1A, RARB2 & Blood & $\begin{array}{l}\text { Diagnosis, } \\
\text { prognosis }\end{array}$ & [168-171] \\
\hline & $-B C A T 1$ and $I K Z F 1$ & Blood & Diagnosis & [172] \\
\hline \multirow{2}{*}{ ncRNAs } & $-\mathrm{miR} 21$ & Blood, saliva & Diagnosis & {$[174,175]$} \\
\hline & -Several miRNA signatures & Blood & Diagnosis & {$[176,177]$} \\
\hline \multicolumn{5}{|c|}{ OTHER CANCER TYPES AND MULTI-CANCER BIOMARKERS } \\
\hline \multirow{5}{*}{ DNA methylation } & -RASFF1A (melanoma) & Blood & Diagnosis & [184] \\
\hline & -MGMT (glioblastoma) & CSF & $\begin{array}{l}\text { Response to } \\
\text { therapy }\end{array}$ & [191] \\
\hline & -RASFF1A, p16, TIMP3 (oral cancer) & Blood, saliva & $\begin{array}{l}\text { Diagnosis, } \\
\text { prognosis }\end{array}$ & [193] \\
\hline & -DNA methylation signature PanSeer ${ }^{\circledR}$ & Blood & Diagnosis & [194] \\
\hline & -DNA methylation signature GRAIL ${ }^{\circledR}$ & Blood & Diagnosis & [169] \\
\hline ncRNAs & -Several miRNA signatures & Blood & Diagnosis & [186-189] \\
\hline
\end{tabular}




\section{Epigenetic Biomarkers in Cancer: Translation to the Clinic}

The use of non-invasive epigenetic biomarkers is considered as a promising option in oncology. However, these biomarkers (with few exceptions) have not successfully reached clinical practice yet. Progress in the path to translation will be made provided clinical value is added to the current management of patients. These are some of the difficulties to take into consideration for clinical translation [195]:

(1) Clinical value and confirmatory results: confirmed clinical evidence in prospective trials is critical for medical professionals and regulatory agencies.

(2) Performance and affordability: it is essential to develop a commercial product with demonstrated good performance, affordable price, and is easy to use.

(3) Pre-analytical issues: preservation of the sample, storage time, and temperature, etc., have to be extensively studied.

(4) Technical barriers: when using some of the epigenetic techniques, there may be a technical barrier, particularly for advanced procedures such as mass spectrometry or next generation sequencing (NGS).

(5) Training: formation on new epigenetic platforms and interpretation of the results is needed, especially for the "omic" epigenetic technologies.

(6) Global regulation: establishing a global harmonization of regulation would facilitate translating an epigenetic assay into the clinic.

Overall, the continuous technological development and commercialization activity of epigenetic kits would lead to an innovative and competitive environment that will result in significant benefits for the clinical practice in the near future.

\section{Conclusions and Future Perspectives}

Evaluation of epigenetic biomarkers in LB is an emerging field in oncology that may help in cancer screening, diagnosis, identification of tumor subtypes as well as in the prediction of response to therapy and outcome. LB offers the opportunity of evaluating tumor markers using non-invasive methods and may represent better tumor heterogeneity and evolution. While the evaluation of actionable mutations in LB has a demonstrated clinical value, the use of epigenetic alterations (with few exceptions) has not reached clinical practice yet. Among the different fields where epigenetic changes may play a role as biomarkers, we envision that screening and diagnosis are the areas closer to the clinic. Current screening tests such as mammography, analysis of occult blood in feces and colonoscopy are routinely performed to detect $\mathrm{BrCa}$ and $\mathrm{CRC}$, respectively. Nonetheless, over-diagnosis and false positives are of concern. In the case of PrCa, blood levels of PSA lack diagnostic accuracy and for $\mathrm{LuCa}$, LDCT is not a common practice yet. Therefore, epigenetic biomarkers in LB could be of great value in screening and diagnosis for these cancer types. Moreover, the development of platforms that analyze thousands of methylation alterations in blood has been shown to be highly valuable in screening for multiple cancers.

Some epigenetic commercial tests have been developed and are currently being evaluated in clinical trials. These tests are designed for individual cancer types or as multi-cancer diagnostic tools; some others include both DNA methylation and mutational assays in the same kit. With constant information being provided by "omic" techniques for both DNA methylation and ncRNAs, new potential sources of epigenetic markers will be introduced and tested. However, the path to clinical translation is long and costly and thus the identified epigenetic biomarkers need to offer an added value over the established clinical practice and to attract investment for their development.

The discovery of new gene/signature candidates can also face several issues. For example, in the case of blood, studies show the need to use large amounts of plasma or serum to evaluate DNA methylation $(1-4 \mathrm{~mL})$ in comparison with protein-based techniques that can use much lower amounts $(10-100 \mu \mathrm{L})$. This limitation could be solved with the introduction of new ultrasensitive techniques. The discovery of novel aberrantly methylated genes using "omic" platforms may also need specialized technicians and bioinformaticians 
to analyze the data correctly. In addition, these technologies are expensive and could be outsourced at reference hospitals.

Supplementary Materials: The following are available online at https:/ /www.mdpi.com/article/10 .3390/ cancers13123016/s1, Table S1: Technologies for epigenetic assays in liquid biopsy, Table S2: Clinical trials using epigenetic biomarkers in $\mathrm{PrCa}, \mathrm{BdCa}$ and RCC.

Author Contributions: Conceptualization: A.C., J.S., E.J.-L., A.D.-L., L.M.; Writing: original draft preparation, C.P.-B., A.R.-C., S.T., S.C.-F., F.E., D.S., E.R., K.V., E.J.-L., A.D.-L., J.S., A.C., review and editing, A.C., J.S., E.J.-L., A.D.-L., L.M. All authors have read and agreed to the published version of the manuscript.

Funding: A.C. and L.M. were funded by FIMA (Foundation for Applied Medical Research), ISCIIIFondo de Investigación Sanitaria-Fondo Europeo de Desarrollo Regional “Una manera de hacer Europa" (PI19/00230, to AC; PI19/00098 to LMM), CIBERONC CB16/12/00443, AECC, and Ramón Areces Foundations (all to L.M.). J.S. was funded by FIS grant (PI19/00572) from the FEDER, FSE, Carlos III Health Institute (ISCIII) and INNVA1/2020/71 de la Línea 1 de Valorización y Transferencia a las empresas, de la Agencia Valenciana de la Innovación. E.J-L. was supported by the Spanish Health Institute Carlos III (ISCII, Fondo de Investigación Sanitaria: CB16/12/00350 and PI18/00266). S.T. was supported by the Generalitat Valenciana and Fondo Social Europeo, fellowship ACIF/2018/275. A.D-L. was funded by a contract Juan Rodés from Spanish Health Institute Carlos III (ISCIII) (JR17/00016) and by a research grant (PI18/00307) co-funded by ISCIII and the European Regional Development Fund (FEDER). A.R-C. was supported by the Roche-CHUS Joint Unit (IN853B2018/03) funded by GAIN, Consellería de Economía, Emprego e Industria". Fellowship support: E.R. "FPU, Spanish Ministry of Education"; D.S., "Juan de la Cierva-Incorporacion, Spanish Ministry of Science and Innovation".

Institutional Review Board Statement: Non-applicable.

Informed Consent Statement: Non-applicable.

Data Availability Statement: Non-applicable.

Conflicts of Interest: Authors declare no conflict of interests.

\section{References}

1. Alvarez, H.; Opalinska, J.; Zhou, L.; Sohal, D.; Fazzari, M.J.; Yu, Y.; Montagna, C.; Montgomery, E.A.; Canto, M.; Dunbar, K.B.; et al. Widespread hypomethylation occurs early and synergizes with gene amplification during esophageal carcinogenesis. PLoS Genet. 2011, 7, e1001356. [CrossRef]

2. Sharma, G.; Dua, P.; Agarwal, S.M. A Comprehensive review of dysregulated MiRNAs involved in cervical cancer. Curr. Genom. 2014, 15, 310-323. [CrossRef] [PubMed]

3. Ross, J.P.; Rand, K.N.; Molloy, P.L. Hypomethylation of repeated DNA sequences in cancer. Epigenomics 2010, 2, $245-269$. [CrossRef]

4. Karimzadeh, M.R.; Pourdavoud, P.; Ehtesham, N.; Qadbeigi, M.; Asl, M.M.; Alani, B.; Mosallaei, M.; Pakzad, B. Regulation of DNA methylation machinery by Epi-MiRNAs in human cancer: Emerging new targets in cancer therapy. Cancer Gene Ther. 2020. [CrossRef] [PubMed]

5. Mutirangura, A. Is global hypomethylation a nidus for molecular pathogenesis of age-related noncommunicable diseases? Epigenomics 2019, 11, 577-579. [CrossRef] [PubMed]

6. Amelio, I.; Bertolo, R.; Bove, P.; Buonomo, O.C.; Candi, E.; Chiocchi, M.; Cipriani, C.; Di Daniele, N.; Ganini, C.; Juhl, H.; et al. Liquid biopsies and cancer omics. Cell Death Discov. 2020, 6, 131. [CrossRef] [PubMed]

7. Locke, W.J.; Guanzon, D.; Ma, C.; Liew, Y.J.; Duesing, K.R.; Fung, K.Y.C.; Ross, J.P. DNA methylation cancer biomarkers: Translation to the clinic. Front. Genet. 2019. [CrossRef]

8. Baylin, S.B.; Jones, P.A. Epigenetic determinants of cancer. Cold Spring Harb. Perspect. Biol. 2016, 8. [CrossRef]

9. Doyle, L.M.; Wang, M.Z. Overview of extracellular vesicles, their origin, composition, purpose, and methods for exosome isolation and analysis. Cells 2019, 8, 727. [CrossRef]

10. Yuan, T.; Huang, X.; Woodcock, M.; Du, M.; Dittmar, R.; Wang, Y.; Tsai, S.; Kohli, M.; Boardman, L.; Patel, T.; et al. Plasma extracellular RNA profiles in healthy and cancer patients. Sci. Rep. 2016. [CrossRef]

11. Ayupe, A.C.; Reis, E.M. Evaluating the stability of MRNAs and noncoding RNAs. In Enhancer RNAs; Methods in Molecular Biology Book Series; Humana Press: Clifton, NJ, USA, 2017; Volume 1468, pp. 139-153. [CrossRef] 
12. Tani, H.; Mizutani, R.; Salam, K.A.; Tano, K.; Ijiri, K.; Wakamatsu, A.; Isogai, T.; Suzuki, Y.; Akimitsu, N. Genome-Wide Determination of RNA Stability reveals hundreds of short-lived noncoding transcripts in mammals. Genome Res. 2012, 22, 947-956. [CrossRef]

13. McDonald, J.S.; Milosevic, D.; Reddi, H.V.; Grebe, S.K.; Algeciras-Schimnich, A. Analysis of circulating MicroRNA: Preanalytical and analytical challenges. Clin. Chem. 2011, 57, 833-840. [CrossRef]

14. Li, I.; Nabet, B.Y. Exosomes in the tumor microenvironment as mediators of cancer therapy resistance. Mol. Cancer 2019, 18, 32. [CrossRef]

15. McAnena, P.; Brown, J.A.L.; Kerin, M.J. Circulating nucleosomes and nucleosome modifications as biomarkers in cancer. Cancers 2017, 9, 5. [CrossRef]

16. Bettegowda, C.; Sausen, M.; Leary, R.J.; Kinde, I.; Wang, Y.; Agrawal, N.; Bartlett, B.R.; Wang, H.; Luber, B.; Alani, R.M.; et al. Detection of circulating tumor DNA in early- and late-stage human malignancies. Sci. Transl. Med. 2014, 6, 224ra24. [CrossRef]

17. Ponti, G.; Manfredini, M.; Tomasi, A. Non-blood sources of cell-free DNA for cancer molecular profiling in clinical pathology and oncology. Crit. Rev. Oncol. Hematol. 2019, 141, 36-42. [CrossRef]

18. Rapado-González, Ó.; López-López, R.; López-Cedrún, J.L.; Triana-Martínez, G.; Muinelo-Romay, L.; Suárez-Cunqueiro, M.M. Cell-free MicroRNAs as potential oral cancer biomarkers: From diagnosis to therapy. Cells 2019, 8, 1653. [CrossRef]

19. Kimura, H.; Fujiwara, Y.; Sone, T.; Kunitoh, H.; Tamura, T.; Kasahara, K.; Nishio, K. High sensitivity detection of epidermal growth factor receptor mutations in the pleural effusion of non-small cell lung cancer patients. Cancer Sci. 2006, 97, 642-648. [CrossRef]

20. O'Reilly, E.; Tuzova, A.V.; Walsh, A.L.; Russell, N.M.; O’Brien, O.; Kelly, S.; Dhomhnallain, O.N.; DeBarra, L.; Dale, C.M.; Brugman, R.; et al. EpiCaPture: A Urine DNA methylation test for early detection of aggressive prostate cancer. JCO Precis. Oncol. 2019, 3. [CrossRef]

21. Van Kessel, K.E.M.; Beukers, W.; Lurkin, I.; Ziel-van der Made, A.; van der Keur, K.A.; Boormans, J.L.; Dyrskjøt, L.; Márquez, M.; Ørntoft, T.F.; Real, F.X.; et al. Validation of a DNA methylation-mutation urine assay to select patients with hematuria for cystoscopy. J. Urol. 2017, 197 Pt 1, 590-595. [CrossRef]

22. Liu, B.-L.; Cheng, J.-X.; Zhang, W.; Zhang, X.; Wang, R.; Lin, H.; Huo, J.-L.; Cheng, H. Quantitative detection of multiple gene promoter hypermethylation in tumor tissue, serum, and cerebrospinal fluid predicts prognosis of malignant gliomas. Neuro Oncol. 2010, 12, 540-548. [CrossRef] [PubMed]

23. Shivapurkar, N.; Gazdar, A.F. DNA methylation based biomarkers in non-invasive cancer screening. Curr. Mol. Med. 2010, 10, 123-132. [CrossRef] [PubMed]

24. Alix-Panabières, C.; Pantel, K. Clinical applications of circulating tumor cells and circulating tumor DNA as liquid biopsy. Cancer Discov. 2016, 6, 479-491. [CrossRef] [PubMed]

25. Wang, Z.; Jiang, W.; Wang, Y.; Guo, Y.; Cong, Z.; DU, F.; Song, B. mgmt promoter methylation in serum and cerebrospinal fluid as a tumor-specific biomarker of glioma. Biomed. Rep. 2015, 3, 543-548. [CrossRef] [PubMed]

26. Pajares, M.J.; Palanca-Ballester, C.; Urtasun, R.; Alemany-Cosme, E.; Lahoz, A.; Sandoval, J. Methods for analysis of specific DNA methylation status. Methods 2021, 187, 3-12. [CrossRef] [PubMed]

27. Bao-Caamano, A.; Rodriguez-Casanova, A.; Diaz-Lagares, A. Epigenetics of circulating tumor cells in breast cancer. Adv. Exp. Med. Biol. 2020, 1220, 117-134. [CrossRef]

28. Han, X.; Wang, J.; Sun, Y. Circulating tumor DNA as biomarkers for cancer detection. Genom. Proteom. Bioinform. 2017, 15, 59-72. [CrossRef]

29. Eads, C.A.; Danenberg, K.D.; Kawakami, K.; Saltz, L.B.; Blake, C.; Shibata, D.; Danenberg, P.V.; Laird, P.W. MethyLight: A high-throughput assay to measure DNA methylation. Nucleic Acids Res. 2000, 28, E32. [CrossRef]

30. Wan, J.C.M.; Massie, C.; Garcia-Corbacho, J.; Mouliere, F.; Brenton, J.D.; Caldas, C.; Pacey, S.; Baird, R.; Rosenfeld, N. Liquid biopsies come of age: Towards implementation of circulating tumour DNA. Nat. Rev. Cancer 2017, 17, 223-238. [CrossRef]

31. Li, M.; Chen, W.-D.; Papadopoulos, N.; Goodman, S.N.; Bjerregaard, N.C.; Laurberg, S.; Levin, B.; Juhl, H.; Arber, N.; Moinova, H.; et al. Sensitive digital quantification of DNA methylation in clinical samples. Nat. Biotechnol. 2009, 27, 858-863. [CrossRef] [PubMed]

32. Radpour, R.; Barekati, Z.; Kohler, C.; Lv, Q.; Bürki, N.; Diesch, C.; Bitzer, J.; Zheng, H.; Schmid, S.; Zhong, X.Y. Hypermethylation of tumor suppressor genes involved in critical regulatory pathways for developing a blood-based test in breast cancer. PLoS ONE 2011, 6, e16080. [CrossRef]

33. Gallardo-Gómez, M.; Moran, S.; Páez de la Cadena, M.; Martínez-Zorzano, V.S.; Rodríguez-Berrocal, F.J.; Rodríguez-Girondo, M.; Esteller, M.; Cubiella, J.; Bujanda, L.; Castells, A.; et al. A new approach to epigenome-wide discovery of non-invasive methylation biomarkers for colorectal cancer screening in circulating cell-free DNA using pooled samples. Clin. Epigenet. 2018, 10, 53. [CrossRef]

34. Solé, C.; Tramonti, D.; Schramm, M.; Goicoechea, I.; Armesto, M.; Hernandez, L.I.; Manterola, L.; Fernandez-Mercado, M.; Mujika, K.; Tuneu, A.; et al. The circulating transcriptome as a source of biomarkers for melanoma. Cancers 2019, 11, 70. [CrossRef]

35. Cojocneanu, R.; Braicu, C.; Raduly, L.; Jurj, A.; Zanoaga, O.; Magdo, L.; Irimie, A.; Muresan, M.-S.; Ionescu, C.; Grigorescu, M.; et al. Plasma and tissue specific MiRNA expression pattern and functional analysis associated to colorectal cancer patients. Cancers 2020, 12, 843. [CrossRef] 
36. Gasparello, J.; Papi, C.; Allegretti, M.; Giordani, E.; Carboni, F.; Zazza, S.; Pescarmona, E.; Romania, P.; Giacomini, P.; Scapoli, C.; et al. A Distinctive MicroRNA (MiRNA) signature in the blood of colorectal cancer (CRC) patients at surgery. Cancers 2020, 12, 2410. [CrossRef]

37. Metcalf, G.A.D.; Shibakawa, A.; Patel, H.; Sita-Lumsden, A.; Zivi, A.; Rama, N.; Bevan, C.L.; Ladame, S. Amplification-free detection of circulating microrna biomarkers from body fluids based on fluorogenic oligonucleotide-templated reaction between engineered peptide-nucleic acid probes: Application to prostate cancer diagnosis. Anal. Chem. 2016, 88, 8091-8098. [CrossRef]

38. Shukla, N.; Yan, I.K.; Patel, T. Multiplexed Detection and Quantitation of Extracellular Vesicle RNA Expression Using NanoString. Methods Mol. Biol. 2018, 1740, 177-185. [CrossRef]

39. Armstrong, D.A.; Green, B.B.; Seigne, J.D.; Schned, A.R.; Marsit, C.J. MicroRNA molecular profiling from matched tumor and bio-fluids in bladder cancer. Mol. Cancer 2015, 14, 194. [CrossRef]

40. Ortega, F.G.; Lorente, J.A.; Garcia Puche, J.L.; Ruiz, M.P.; Sanchez-Martin, R.M.; de Miguel-Pérez, D.; Diaz-Mochon, J.J.; Serrano, M.J. MiRNA in situ hybridization in circulating tumor cells-MishCTC. Sci. Rep. 2015, 5, 9207. [CrossRef]

41. Li, L.; Lu, M.; Fan, Y.; Shui, L.; Xie, S.; Sheng, R.; Si, H.; Li, Q.; Wang, Y.; Tang, B. High-throughput and ultra-sensitive single-cell profiling of multiple MicroRNAs and identification of human cancer. Chem. Commun. 2019, 55, 10404-10407. [CrossRef] [PubMed]

42. Hurd, P.J.; Nelson, C.J. Advantages of next-generation sequencing versus the microarray in epigenetic research. Brief. Funct. Genom. Proteom. 2009, 8, 174-183. [CrossRef] [PubMed]

43. Wang, Y.-M.; Trinh, M.P.; Zheng, Y.; Guo, K.; Jimenez, L.A.; Zhong, W. Analysis of circulating non-coding RNAs in a non-invasive and cost-effective manner. Trends Anal. Chem. TRAC 2019, 117, 242-262. [CrossRef] [PubMed]

44. Sung, H.; Ferlay, J.; Siegel, R.L.; Laversanne, M.; Soerjomataram, I.; Jemal, A.; Bray, F. Global Cancer Statistics 2020: GLOBOCAN estimates of incidence and mortality worldwide for 36 cancers in 185 countries. CA Cancer J. Clin. 2021. [CrossRef]

45. Siegel, R.L.; Miller, K.D.; Jemal, A. Cancer statistics, 2019. CA Cancer J. Clin. 2019, 69, 7-34. [CrossRef]

46. Krist, A.H.; Davidson, K.W.; Mangione, C.M.; Barry, M.J.; Cabana, M.; Caughey, A.B.; Davis, E.M.; Donahue, K.E.; Doubeni, C.A.; Kubik, M.; et al. Screening for lung cancer: US preventive services task force recommendation statement. JAMA 2021, 325, 962-970. [CrossRef]

47. Seijo, L.M.; Peled, N.; Ajona, D.; Boeri, M.; Field, J.K.; Sozzi, G.; Pio, R.; Zulueta, J.J.; Spira, A.; Massion, P.P.; et al. Biomarkers in lung cancer screening: Achievements, promises, and challenges. J. Thorac. Oncol. 2019, 14, 343-357. [CrossRef]

48. Schmidt, B.; Beyer, J.; Dietrich, D.; Bork, I.; Liebenberg, V.; Fleischhacker, M. Quantification of cell-free MSHOX2 plasma DNA for therapy monitoring in advanced stage non-small cell (NSCLC) and small-cell lung cancer (SCLC) patients. PLoS ONE 2015, 10, e0118195. [CrossRef]

49. Kneip, C.; Schmidt, B.; Seegebarth, A.; Weickmann, S.; Fleischhacker, M.; Liebenberg, V.; Field, J.K.; Dietrich, D. SHOX2 DNA methylation is a biomarker for the diagnosis of lung cancer in plasma. J. Thorac. Oncol. 2011, 6, 1632-1638. [CrossRef]

50. Konecny, M.; Markus, J.; Waczulikova, I.; Dolesova, L.; Kozlova, R.; Repiska, V.; Novosadova, H.; Majer, I. The Value of SHOX2 methylation test in peripheral blood samples used for the differential diagnosis of lung cancer and other lung disorders. Neoplasma 2016, 63, 246-253. [CrossRef]

51. Ilse, P.; Biesterfeld, S.; Pomjanski, N.; Fink, C.; Schramm, M. SHOX2 DNA methylation is a tumour marker in pleural effusions. Cancer Genom. Proteom. 2013, 10, 217-223.

52. Powrózek, T.; Krawczyk, P.; Nicoś, M.; Kuźnar-Kamińska, B.; Batura-Gabryel, H.; Milanowski, J. Methylation of the DCLK1 promoter region in circulating free DNA and its prognostic value in lung cancer patients. Clin. Transl. Oncol. 2016, 18, 398-404. [CrossRef]

53. Powrózek, T.; Krawczyk, P.; Kucharczyk, T.; Milanowski, J. Septin 9 promoter region methylation in free circulating DNA-potential role in noninvasive diagnosis of lung cancer: Preliminary report. Med. Oncol. 2014, 31, 917. [CrossRef]

54. Ponomaryova, A.A.; Rykova, E.Y.; Cherdyntseva, N.V.; Skvortsova, T.E.; Dobrodeev, A.Y.; Zav'yalov, A.A.; Bryzgalov, L.O.; Tuzikov, S.A.; Vlassov, V.V.; Laktionov, P.P. Potentialities of aberrantly methylated circulating DNA for diagnostics and posttreatment follow-up of lung cancer patients. Lung Cancer 2013, 81, 397-403. [CrossRef]

55. Hulbert, A.; Jusue-Torres, I.; Stark, A.; Chen, C.; Rodgers, K.; Lee, B.; Griffin, C.; Yang, A.; Huang, P.; Wrangle, J.; et al. Early detection of lung cancer using DNA promoter hypermethylation in plasma and sputum. Clin. Cancer Res. 2017, 23, 1998-2005. [CrossRef]

56. Liu, D.; Peng, H.; Sun, Q.; Zhao, Z.; Yu, X.; Ge, S.; Wang, H.; Fang, H.; Gao, Q.; Liu, J.; et al. The indirect efficacy comparison of DNA methylation in sputum for early screening and auxiliary detection of lung cancer: A meta-analysis. Int. J. Environ. Res. Public Health 2017, 14, 679. [CrossRef]

57. Liu, B.; Ricarte Filho, J.; Mallisetty, A.; Villani, C.; Kottorou, A.; Rodgers, K.; Chen, C.; Ito, T.; Holmes, K.; Gastala, N.; et al. Detection of promoter DNA methylation in urine and plasma aids the detection of non-small cell lung cancer. Clin. Cancer Res. 2020, 26, 4339-4348. [CrossRef]

58. Diaz-Lagares, A.; Mendez-Gonzalez, J.; Hervas, D.; Saigi, M.; Pajares, M.J.; Garcia, D.; Crujerias, A.B.; Pio, R.; Montuenga, L.M.; Zulueta, J.; et al. A novel epigenetic signature for early diagnosis in lung cancer. Clin. Cancer Res. 2016, 22, 3361-3371. [CrossRef]

59. Exposito, F.; Villalba, M.; Redrado, M.; de Aberasturi, A.L.; Cirauqui, C.; Redin, E.; Guruceaga, E.; de Andrea, C.; Vicent, S.; Ajona, D.; et al. Targeting of TMPRSS4 sensitizes lung cancer cells to chemotherapy by impairing the proliferation machinery. Cancer Lett. 2019, 453, 21-33. [CrossRef] 
60. Hsu, H.-S.; Chen, T.-P.; Hung, C.-H.; Wen, C.-K.; Lin, R.-K.; Lee, H.-C.; Wang, Y.-C. Characterization of a multiple epigenetic marker panel for lung cancer detection and risk assessment in plasma. Cancer 2007, 110, 2019-2026. [CrossRef]

61. Ostrow, K.L.; Hoque, M.O.; Loyo, M.; Brait, M.; Greenberg, A.; Siegfried, J.M.; Grandis, J.R.; Gaither Davis, A.; Bigbee, W.L.; Rom, W.; et al. Molecular analysis of plasma DNA for the early detection of lung cancer by quantitative methylation-specific PCR. Clin. Cancer Res. 2010, 16, 3463-3472. [CrossRef]

62. Ooki, A.; Maleki, Z.; Tsay, J.-C.J.; Goparaju, C.; Brait, M.; Turaga, N.; Nam, H.-S.; Rom, W.N.; Pass, H.I.; Sidransky, D.; et al. A Panel of novel detection and prognostic methylated dna markers in primary non-small cell lung cancer and serum DNA. Clin. Cancer Res. 2017, 23, 7141-7152. [CrossRef]

63. Constâncio, V.; Nunes, S.P.; Henrique, R.; Jerónimo, C. DNA methylation-based testing in liquid biopsies as detection and prognostic biomarkers for the four major cancer types. Cells 2020, 9, 624. [CrossRef]

64. Lissa, D.; Robles, A.I. Methylation analyses in liquid biopsy. Transl. Lung Cancer Res. 2016, 5, 492-504. [CrossRef]

65. Vinayanuwattikun, C.; Sriuranpong, V.; Tanasanvimon, S.; Chantranuwat, P.; Mutirangura, A. Epithelial-Specific Methylation marker: A potential plasma biomarker in advanced non-small cell lung cancer. J. Thorac. Oncol. 2011, 6, 1818-1825. [CrossRef]

66. Balgkouranidou, I.; Chimonidou, M.; Milaki, G.; Tsarouxa, E.G.; Kakolyris, S.; Welch, D.R.; Georgoulias, V.; Lianidou, E.S. Breast cancer metastasis suppressor-1 promoter methylation in cell-free DNA provides prognostic information in non-small cell lung cancer. Br. J. Cancer 2014, 110, 2054-2062. [CrossRef]

67. Balgkouranidou, I.; Chimonidou, M.; Milaki, G.; Tsaroucha, E.; Kakolyris, S.; Georgoulias, V.; Lianidou, E. SOX17 promoter methylation in plasma circulating tumor DNA of patients with non-small cell lung cancer. Clin. Chem. Lab. Med. 2016, 54, 1385-1393. [CrossRef]

68. Ramirez, J.L.; Rosell, R.; Taron, M.; Sanchez-Ronco, M.; Alberola, V.; de Las Peñas, R.; Sanchez, J.M.; Moran, T.; Camps, C.; Massuti, B.; et al. 14-3-3sigma methylation in pretreatment serum circulating DNA of cisplatin-plus-gemcitabine-treated advanced nonsmall-cell lung cancer patients predicts survival: The Spanish lung cancer group. J. Clin. Oncol. 2005, 23, 9105-9112. [CrossRef] [PubMed]

69. Salazar, F.; Molina, M.A.; Sanchez-Ronco, M.; Moran, T.; Ramirez, J.L.; Sanchez, J.M.; Stahel, R.; Garrido, P.; Cobo, M.; Isla, D.; et al. First-line therapy and methylation status of CHFR in serum influence outcome to chemotherapy versus EGFR tyrosine kinase inhibitors as second-line therapy in stage IV non-small-cell lung cancer patients. Lung Cancer 2011, 72, 84-91. [CrossRef] [PubMed]

70. Wang, H.; Zhang, B.; Chen, D.; Xia, W.; Zhang, J.; Wang, F.; Xu, J.; Zhang, Y.; Zhang, M.; Zhang, L.; et al. Real-time monitoring efficiency and toxicity of chemotherapy in patients with advanced lung cancer. Clin. Epigenet. 2015, 7, 119. [CrossRef] [PubMed]

71. Shen, J.; Wang, S.; Zhang, Y.-J.; Kappil, M.A.; Chen Wu, H.; Kibriya, M.G.; Wang, Q.; Jasmine, F.; Ahsan, H.; Lee, P.-H.; et al. Genome-wide aberrant DNA methylation of MicroRNA host genes in hepatocellular carcinoma. Epigenetics 2012, 7, $1230-1237$. [CrossRef]

72. Gao, X.; Wang, Y.; Zhao, H.; Wei, F.; Zhang, X.; Su, Y.; Wang, C.; Li, H.; Ren, X. Plasma MiR-324-3p and MiR-1285 as Diagnostic and prognostic biomarkers for early stage lung squamous cell carcinoma. Oncotarget 2016, 7, 59664-59675. [CrossRef]

73. Chen, X.; Hu, Z.; Wang, W.; Ba, Y.; Ma, L.; Zhang, C.; Wang, C.; Ren, Z.; Zhao, Y.; Wu, S.; et al. Identification of ten serum MicroRNAs from a genome-wide serum MicroRNA expression profile as novel noninvasive biomarkers for nonsmall cell lung cancer diagnosis. Int. J. Cancer 2012, 130, 1620-1628. [CrossRef]

74. Yu, H.; Guan, Z.; Cuk, K.; Zhang, Y.; Brenner, H. Circulating MicroRNA biomarkers for lung cancer detection in east Asian populations. Cancers 2019, 11, 415. [CrossRef]

75. Fehlmann, T.; Kahraman, M.; Ludwig, N.; Backes, C.; Galata, V.; Keller, V.; Geffers, L.; Mercaldo, N.; Hornung, D.; Weis, T.; et al. Evaluating the use of circulating MicroRNA profiles for lung cancer detection in symptomatic patients. JAMA Oncol. 2020, 6, 714-723. [CrossRef]

76. Powrózek, T.; Kuźnar-Kamińska, B.; Dziedzic, M.; Mlak, R.; Batura-Gabryel, H.; Sagan, D.; Krawczyk, P.; Milanowski, J.; Małecka-Massalska, T. The diagnostic role of plasma circulating precursors of MiRNA-944 and MiRNA-3662 for non-small cell lung cancer detection. Pathol. Res. Pract. 2017, 213, 1384-1387. [CrossRef]

77. Ulivi, P.; Petracci, E.; Marisi, G.; Baglivo, S.; Chiari, R.; Billi, M.; Canale, M.; Pasini, L.; Racanicchi, S.; Vagheggini, A.; et al. Prognostic role of circulating MiRNAs in early-stage non-small cell lung cancer. J. Clin. Med. 2019, 8, 131. [CrossRef]

78. Yanaihara, N.; Caplen, N.; Bowman, E.; Seike, M.; Kumamoto, K.; Yi, M.; Stephens, R.M.; Okamoto, A.; Yokota, J.; Tanaka, T.; et al. Unique MicroRNA molecular profiles in lung cancer diagnosis and prognosis. Cancer Cell 2006, 9, 189-198. [CrossRef]

79. Xie, Y.; Zhang, Y.; Du, L.; Jiang, X.; Yan, S.; Duan, W.; Li, J.; Zhan, Y.; Wang, L.; Zhang, S.; et al. Circulating long noncoding RNA act as potential novel biomarkers for diagnosis and prognosis of non-small cell lung cancer. Mol. Oncol. 2018, 12, 648-658. [CrossRef]

80. Luo, Y.-H.; Yang, Y.-P.; Chien, C.-S.; Yarmishyn, A.A.; Ishola, A.A.; Chien, Y.; Chen, Y.-M.; Huang, T.-W.; Lee, K.-Y.; Huang, W.-C.; et al. Plasma level of circular RNA Hsa_circ_0000190 correlates with tumor progression and poor treatment response in advanced lung cancers. Cancers 2020, 12, 1740. [CrossRef]

81. Li, B.; Ren, S.; Li, X.; Wang, Y.; Garfield, D.; Zhou, S.; Chen, X.; Su, C.; Chen, M.; Kuang, P.; et al. MiR-21 Overexpression is associated with acquired resistance of EGFR-TKI in non-small cell lung cancer. Lung Cancer 2014, 83, 146-153. [CrossRef] 
82. Wang, S.; Su, X.; Bai, H.; Zhao, J.; Duan, J.; An, T.; Zhuo, M.; Wang, Z.; Wu, M.; Li, Z.; et al. Identification of plasma MicroRNA profiles for primary resistance to EGFR-TKIs in advanced non-small cell lung cancer (NSCLC) patients with EGFR activating mutation. J. Hematol. Oncol. 2015, 8, 127. [CrossRef]

83. Fan, J.; Yin, Z.; Xu, J.; Wu, F.; Huang, Q.; Yang, L.; Jin, Y.; Yang, G. Circulating MicroRNAs predict the response to Anti-PD-1 therapy in non-small cell lung cancer. Genomics 2020, 112, 2063-2071. [CrossRef]

84. International Agency for Research on Cancer (IARC). W.H.O. GLOBOCAN. 2020. Available online: https://gco.iarc.fr/today/ home (accessed on 15 June 2021).

85. Culp, M.B.B.; Soerjomataram, I.; Efstathiou, J.A.; Bray, F.; Jemal, A. Recent global patterns in prostate cancer incidence and mortality rates. Eur. Urol. 2020, 38-52. [CrossRef]

86. Hoque, M.O.; Begum, S.; Topaloglu, O.; Chatterjee, A.; Rosenbaum, E.; Van Criekinge, W.; Westra, W.H.; Schoenberg, M.; Zahurak, M.; Goodman, S.N.; et al. Quantitation of promoter methylation of multiple genes in urine DNA and bladder cancer detection. J. Natl. Cancer Inst. 2006, 98, 996-1004. [CrossRef]

87. Porzycki, P.; Ciszkowicz, E. Modern biomarkers in prostate cancer diagnosis. Cent. Eur. J. Urol. 2020, 300-306. [CrossRef]

88. Saginala, K.; Barsouk, A.; Aluru, J.S.; Rawla, P.; Padala, S.A.; Barsouk, A. Epidemiology of bladder cancer. Med. Sci. 2020, 8, 15. [CrossRef]

89. Berdik, C.; Ashour, M. Unlocking Bladder Cancer. Nature 2017, S34-S35. [CrossRef] [PubMed]

90. Padala, S.A.; Barsouk, A.; Thandra, K.C.; Saginala, K.; Mohammed, A.; Vakiti, A.; Rawla, P.; Barsouk, A. Epidemiology of renal cell carcinoma. World J. Oncol. 2020, 11, 79-87. [CrossRef] [PubMed]

91. Wu, P.; Cao, Z.; Wu, S. New progress of epigenetic biomarkers in urological cancer. Dis. Markers 2016. [CrossRef] [PubMed]

92. Lasseigne, B.N.; Brooks, J.D. The Role of DNA Methylation in renal cell carcinoma. Mol. Diagn. Ther. 2018, 431-442. [CrossRef]

93. Zill, O.A.; Banks, K.C.; Fairclough, S.R.; Mortimer, S.A.; Vowles, J.V.; Mokhtari, R.; Gandara, D.R.; Mack, P.C.; Odegaard, J.I.; Nagy, R.J.; et al. The landscape of actionable genomic alterations in cell-free circulating tumor DNA from 21,807 advanced cancer patients. Clin. Cancer Res. 2018, 24, 3528-3538. [CrossRef]

94. Gurioli, G.; Martignano, F.; Salvi, S.; Costantini, M.; Gunelli, R.; Casadio, V. GSTP1 methylation in cancer: A liquid biopsy biomarker? Clin. Chem. Lab. Med. 2018, 705-717. [CrossRef]

95. Wu, T.; Giovannucci, E.; Welge, J.; Mallick, P.; Tang, W.Y.; Ho, S.M. Measurement of GSTP1 promoter methylation in body fluids may complement PSA screening: A meta-analysis. Br. J. Cancer 2011, 105, 65-73. [CrossRef]

96. Payne, S.R.; Serth, J.; Schostak, M.; Kamradt, J.; Strauss, A.; Thelen, P.; Model, F.; Day, J.K.; Liebenberg, V.; Morotti, A.; et al. DNA methylation biomarkers of prostate cancer: Confirmation of candidates and evidence urine is the most sensitive body fluid for non-invasive detection. Prostate 2009, 69, 1257-1269. [CrossRef]

97. Goessl, C.; Müller, M.; Heicappell, R.; Krause, H.; Miller, K. DNA-Based detection of prostate cancer in blood, urine, and ejaculates. Ann. N. Y. Acad. Sci. 2001, 945, 51-58. [CrossRef]

98. Sunami, E.; Shinozaki, M.; Higano, C.S.; Wollman, R.; Dorff, T.B.; Tucker, S.J.; Martinez, S.R.; Singer, F.R.; Hoon, D.S.B. Multimarker circulating DNA assay for assessing blood of prostate cancer patients. Clin. Chem. 2009, 55, 559-567. [CrossRef]

99. Hauser, S.; Tobias, Z.; Fechner, G.; Lummen, G.; Muller, S.C.; Ellinger, J. Serum DNA hypermethylation in patients with kidney cancer: Results of a prospective study. Anticancer Res. 2013, 33, 4651-4656.

100. Hoque, M.O.; Begum, S.; Topaloglu, O.; Jeronimo, C.; Mambo, E.; Westra, W.H.; Califano, J.A.; Sidransky, D. Quantitative detection of promoter hypermethylation of multiple genes in the tumor, urine, and serum DNA of patients with renal cancer. Cancer Res. 2004, 64, 5511-5517. [CrossRef]

101. Brait, M.; Banerjee, M.; Maldonado, L.; Ooki, A.; Loyo, M.; Guida, E.; Izumchenko, E.; Mangold, L.; Humphreys, E.; Rosenbaum, E.; et al. Promoter methylation of MCAM, ERa and ER $\beta$ in serum of early stage prostate cancer patients. Oncotarget 2017, 8, 15431-15440. [CrossRef]

102. Haldrup, C.; Pedersen, A.L.; Øgaard, N.; Strand, S.H.; Høyer, S.; Borre, M.; Ørntoft, T.F.; Sørensen, K.D. Biomarker potential of ST6GALNAC3 and ZNF660 promoter hypermethylation in prostate cancer tissue and liquid biopsies. Mol. Oncol. 2018, 12, 545-560. [CrossRef]

103. Lin, Y.L.; Sun, G.; Liu, X.Q.; Li, W.P.; Ma, J.G. Clinical significance of CDH13 promoter methylation in serum samples from patients with bladder transitional cell carcinoma. J. Int. Med. Res. 2011, 39, 179-186. [CrossRef] [PubMed]

104. Lin, Y.L.; Li, Z.G.; He, Z.K.; Guan, T.Y.; Ma, J.Q. Clinical and prognostic significance of protocadherin-10 (PCDH10) promoter methylation in bladder cancer. J. Int. Med. Res. 2012, 40, 2117-2123. [CrossRef] [PubMed]

105. Luo, Z.G.; Li, Z.G.; Gui, S.L.; Chi, B.J.; Ma, J.G. Protocadherin-17 promoter methylation in serum-derived dna is associated with poor prognosis of bladder cancer. J. Int. Med. Res. 2014, 42, 35-41. [CrossRef] [PubMed]

106. Wang, Y.; Yu, Y.; Ye, R.; Zhang, D.; Li, Q.; An, D.; Fang, L.; Lin, Y.; Hou, Y.; Xu, A.; et al. An epigenetic biomarker combination of PCDH17 and POU4F2 detects bladder cancer accurately by methylation analyses of urine sediment DNA in Han Chinese. Oncotarget 2016, 7, 2754-2764. [CrossRef]

107. Fantony, J.J.; Longo, T.A.; Gopalakrishna, A.; Owusu, R.; Lance, R.S.; Foo, W.C.; Inman, B.A.; Abern, M.R. Urinary NID2 and TWIST1 methylation to augment conventional urine cytology for the detection of bladder cancer. Cancer Biomark. 2017, 18, 381-387. [CrossRef] 
108. Hermanns, T.; Savio, A.J.; Olkhov-Mitsel, E.; Mari, A.; Wettstein, M.S.; Saba, K.; Bhindi, B.; Kuk, C.; Poyet, C.; Wild, P.J.; et al. A Noninvasive urine-based methylation biomarker panel to detect bladder cancer and discriminate cancer grade. Urol. Oncol. Semin. Orig. Investig. 2020, 38, 603.e1-603.e7. [CrossRef]

109. Urakami, S.; Shiina, H.; Enokida, H.; Hirata, H.; Kawamoto, K.; Kawakami, T.; Kikuno, N.; Tanaka, Y.; Majid, S.; Nakagawa, M.; et al. Wnt antagonist family genes as biomarkers for diagnosis, staging, and prognosis of renal cell carcinoma using tumor and serum DNA. Clin. Cancer Res. 2006, 12, 6989-6997. [CrossRef]

110. Nuzzo, P.V.; Berchuck, J.E.; Korthauer, K.; Spisak, S.; Nassar, A.H.; Abou Alaiwi, S.; Chakravarthy, A.; Shen, S.Y.; Bakouny, Z.; Boccardo, F.; et al. Detection of renal cell carcinoma using plasma and urine cell-free DNA methylomes. Nat. Med. 2020, 26, 1041-1043. [CrossRef]

111. Vener, T.; Derecho, C.; Baden, J.; Wang, H.; Rajpurohit, Y.; Skelton, J.; Mehrotra, J.; Varde, S.; Chowdary, D.; Stallings, W.; et al. Development of a multiplexed urine assay for prostate cancer diagnosis. Clin. Chem. 2008, 54, 874-882. [CrossRef]

112. Kawamoto, K.; Enokida, H.; Gotanda, T.; Kubo, H.; Nishiyama, K.; Kawahara, M.; Nakagawa, M. P16INK4a and P14ARF methylation as a potential biomarker for human bladder cancer. Biochem. Biophys. Res. Commun. 2006, 339, 790-796. [CrossRef]

113. Moreira-Barbosa, C.; Barros-Silva, D.; Costa-Pinheiro, P.; Torres-Ferreira, J.; Constâncio, V.; Freitas, R.; Oliveira, J.; Antunes, L.; Henrique, R.; Jerónimo, C. Comparing diagnostic and prognostic performance of two-gene promoter methylation panels in tissue biopsies and urines of prostate cancer patients. Clin. Epigenet. 2018, 10. [CrossRef]

114. Jatkoe, T.A.; Karnes, R.J.; Freedland, S.J.; Wang, Y.; Le, A.; Baden, J. A urine-based methylation signature for risk stratification within low-risk prostate cancer. Br. J. Cancer 2015, 112, 802-808. [CrossRef]

115. Zhao, F.; Olkhov-Mitsel, E.; van der Kwast, T.; Sykes, J.; Zdravic, D.; Venkateswaran, V.; Zlotta, A.R.; Loblaw, A.; Fleshner, N.E.; Klotz, L.; et al. Urinary DNA methylation biomarkers for noninvasive prediction of aggressive disease in patients with prostate cancer on active surveillance. J. Urol. 2017, 197, 335-341. [CrossRef]

116. Zhao, F.; Olkhov-Mitsel, E.; Kamdar, S.; Jeyapala, R.; Garcia, J.; Hurst, R.; Hanna, M.Y.; Mills, R.; Tuzova, A.V.; O’Reilly, E.; et al. A urine-based DNA methylation assay, ProCUrE, to identify clinically significant prostate cancer 11 medical and health sciences 1112 oncology and carcinogenesis. Clin. Epigenet. 2018, 10. [CrossRef]

117. Reinert, T.; Borre, M.; Christiansen, A.; Hermann, G.G.; Ørntoft, T.F.; Dyrskjøt, L. Diagnosis of bladder cancer recurrence based on urinary levels of EOMES, HOXA9, POU4F2, TWIST1, VIM, and ZNF154 hypermethylation. PLoS ONE 2012, 7, e46297. [CrossRef]

118. Yu, X.; Wang, R.; Han, C.; Wang, Z.; Jin, X. A panel of urinary long non-coding RNAs differentiate bladder cancer from urocystitis. J. Cancer 2020, 11, 781-787. [CrossRef]

119. Du, L.; Jiang, X.; Duan, W.; Wang, R.; Wang, L.; Zheng, G.; Yan, K.; Wang, L.; Li, J.; Zhang, X.; et al. Cell-Free MicroRNA expression signatures in urine serve as novel noninvasive biomarkers for diagnosis and recurrence prediction of bladder cancer. Oncotarget 2017, 8, 40832-40842. [CrossRef]

120. Urquidi, V.; Netherton, M.; Gomes-Giacoia, E.; Serie, D.J.; Eckel-Passow, J.; Rosser, C.J.; Goodison, S. A MicroRNA biomarker panel for the non-invasive detection of bladder cancer. Oncotarget 2016, 7, 86290-86299. [CrossRef]

121. Eissa, S.; Matboli, M.; Essawy, N.O.E.; Kotb, Y.M. Integrative functional genetic-epigenetic approach for selecting genes as urine biomarkers for bladder cancer diagnosis. Tumour Biol. 2015, 36, 9545-9552. [CrossRef]

122. Fan, Y.; Shen, B.; Tan, M.; Mu, X.; Qin, Y.; Zhang, F.; Liu, Y. Long Non-Coding RNA UCA1 increases chemoresistance of bladder cancer cells by regulating wnt signaling. FEBS J. 2014, 281, 1750-1758. [CrossRef]

123. Urabe, F.; Matsuzaki, J.; Yamamoto, Y.; Kimura, T.; Hara, T.; Ichikawa, M.; Takizawa, S.; Aoki, Y.; Niida, S.; Sakamoto, H.; et al. Large-scale circulating MicroRNA profiling for the liquid biopsy of prostate cancer. Clin. Cancer Res. 2019, 25, $3016-3025$. [CrossRef] [PubMed]

124. Mello-Grand, M.; Gregnanin, I.; Sacchetto, L.; Ostano, P.; Zitella, A.; Bottoni, G.; Oderda, M.; Marra, G.; Munegato, S.; Pardini, B.; et al. Circulating MicroRNAs combined with PSA for accurate and non-invasive prostate cancer detection. Carcinogenesis 2019, 40, 246-253. [CrossRef] [PubMed]

125. Porzycki, P.; Ciszkowicz, E.; Semik, M.; Tyrka, M. Combination of three MiRNA (MiR-141, MiR-21, and MiR-375) as potential diagnostic tool for prostate cancer recognition. Int. Urol. Nephrol. 2018, 50, 1619-1626. [CrossRef] [PubMed]

126. Bayo, J.; Castaño, M.A.; Rivera, F.; Navarro, F. Analysis of blood markers for early breast cancer diagnosis. Clin. Transl. Oncol. 2018, 20, 467-475. [CrossRef]

127. Melnikow, J.; Fenton, J.J.; Whitlock, E.P.; Miglioretti, D.L.; Weyrich, M.S.; Thompson, J.H.; Shah, K. Supplemental screening for breast cancer in women with dense breasts: A systematic review for the U.S. preventive services task force. Ann. Intern. Med. 2016, 164, 268-278. [CrossRef]

128. Miller, A.B.; Wall, C.; Baines, C.J.; Sun, P.; To, T.; Narod, S.A. Twenty five year follow-up for breast cancer incidence and mortality of the canadian national breast screening study: Randomised screening trial. BMJ 2014, 348, g366. [CrossRef]

129. Dulaimi, E.; Hillinck, J.; Ibanez de Caceres, I.; Al-Saleem, T.; Cairns, P. Tumor suppressor gene promoter hypermethylation in serum of breast cancer patients. Clin. Cancer Res. 2004, 1018 Pt 1, 6189-6193. [CrossRef]

130. Hoque, M.O.; Feng, Q.; Toure, P.; Dem, A.; Critchlow, C.W.; Hawes, S.E.; Wood, T.; Jeronimo, C.; Rosenbaum, E.; Stern, J.; et al. Detection of aberrant methylation of four genes in plasma DNA for the detection of breast cancer. J. Clin. Oncol. 2006, 24, 4262-4269. [CrossRef] 
131. Skvortsova, T.E.; Rykova, E.Y.; Tamkovich, S.N.; Bryzgunova, O.E.; Starikov, A.V.; Kuznetsova, N.P.; Vlassov, V.V.; Laktionov, P.P. Cell-Free and cell-bound circulating DNA in breast tumours: DNA quantification and analysis of tumour-related gene methylation. Br. J. Cancer 2006, 94, 1492-1495. [CrossRef]

132. Yamamoto, N.; Nakayama, T.; Kajita, M.; Miyake, T.; Iwamoto, T.; Kim, S.J.; Sakai, A.; Ishihara, H.; Tamaki, Y.; Noguchi, S. Detection of aberrant promoter methylation of GSTP1, RASSF1A, and RAR $\beta 2$ in serum DNA of patients with breast cancer by a newly established one-step methylation-specific PCR assay. Breast Cancer Res. Treat. 2012, 132, 165-173. [CrossRef]

133. Han, Z.-H.; Xu, C.-S.; Han, H.; Wang, C.; Lin, S.-G. Value of the level of methylation of RASSF1A and WIF-1 in tissue and serum in neoadjuvant chemotherapeutic assessment for advanced breast cancer. Oncol. Lett. 2017, 14, 4499-4504. [CrossRef]

134. Taryma-Leśniak, O.; Sokolowska, K.E.; Wojdacz, T.K. Current status of development of methylation biomarkers for in vitro diagnostic IVD applications. Clin. Epigenet. 2020, 12, 100. [CrossRef]

135. Ozawa, P.M.M.; Vieira, E.; Lemos, D.S.; Souza, I.L.M.; Zanata, S.M.; Pankievicz, V.C.; Tuleski, T.R.; Souza, E.M.; Wowk, P.F.; de Andrade Urban, C.; et al. Identification of MiRNAs enriched in extracellular vesicles derived from serum samples of breast cancer patients. Biomolecules 2020, 10, 150. [CrossRef]

136. Schwarzenbach, H.; Pantel, K. Circulating DNA as biomarker in breast cancer. Breast Cancer Res. 2015, 17, 136. [CrossRef]

137. Chimonidou, M.; Kallergi, G.; Georgoulias, V.; Welch, D.R.; Lianidou, E.S. Breast cancer metastasis suppressor-1 promoter methylation in primary breast tumors and corresponding circulating tumor cells. Mol. Cancer Res. 2013, 11, 1248-1257. [CrossRef]

138. Chimonidou, M.; Tzitzira, A.; Strati, A.; Sotiropoulou, G.; Sfikas, C.; Malamos, N.; Georgoulias, V.; Lianidou, E. CST6 promoter methylation in circulating cell-free DNA of breast cancer patients. Clin. Biochem. 2013, 46, 235-240. [CrossRef]

139. Sharma, G.; Mirza, S.; Parshad, R.; Srivastava, A.; Gupta, S.D.; Pandya, P.; Ralhan, R. Clinical significance of maspin promoter methylation and loss of its protein expression in invasive ductal breast carcinoma: Correlation with VEGF-A and MTA1 expression. Tumour Biol. 2011, 32, 23-32. [CrossRef]

140. De Ruijter, T.C.; van der Heide, F.; Smits, K.M.; Aarts, M.J.; van Engeland, M.; Heijnen, V.C.G. Prognostic DNA methylation markers for hormone receptor breast cancer: A systematic review. Breast Cancer Res. BCR 2020, 22, 13. [CrossRef]

141. Huang, Y.-T.; Li, F.-F.; Ke, C.; Li, Z.; Li, Z.-T.; Zou, X.-F.; Zheng, X.-X.; Chen, Y.-P.; Zhang, H. PTPRO promoter methylation is predictive of poorer outcome for HER2-positive breast cancer: Indication for personalized therapy. J. Transl. Med. 2013, 11, 245 [CrossRef]

142. Chimonidou, M.; Strati, A.; Malamos, N.; Georgoulias, V.; Lianidou, E.S. sox17 promoter methylation in circulating tumor cells and matched cell-free DNA isolated from plasma of patients with breast cancer. Clin. Chem. 2013, 59, 270-279. [CrossRef]

143. Fu, D.; Ren, C.; Tan, H.; Wei, J.; Zhu, Y.; He, C.; Shao, W.; Zhang, J. Sox17 promoter methylation in plasma DNA is associated with poor survival and can be used as a prognostic factor in breast cancer. Medicine 2015, 94, e637. [CrossRef] [PubMed]

144. Church, T.R.; Wandell, M.; Lofton-Day, C.; Mongin, S.J.; Burger, M.; Payne, S.R.; Castaños-Vélez, E.; Blumenstein, B.A.; Rösch, T.; Osborn, N.; et al. Prospective evaluation of methylated SEPT9 in plasma for detection of asymptomatic colorectal cancer. Gut 2014, 63, 317-325. [CrossRef] [PubMed]

145. Absmaier, M.; Napieralski, R.; Schuster, T.; Aubele, M.; Walch, A.; Magdolen, V.; Dorn, J.; Gross, E.; Harbeck, N.; Noske, A.; et al. PITX2 DNA-methylation predicts response to anthracycline-based adjuvant chemotherapy in triple-negative breast cancer patients. Int. J. Oncol. 2018, 52, 755-767. [CrossRef] [PubMed]

146. Martínez-Galán, J.; Torres-Torres, B.; Núñez, M.I.; López-Peñalver, J.; Del Moral, R.; Ruiz De Almodóvar, J.M.; Menjón, S.; Concha, A.; Chamorro, C.; Ríos, S.; et al. ESR1 gene promoter region methylation in free circulating DNA and its correlation with estrogen receptor protein expression in tumor tissue in breast cancer patients. BMC Cancer 2014, 14, 59. [CrossRef]

147. Visvanathan, K.; Fackler, M.S.; Zhang, Z.; Lopez-Bujanda, Z.A.; Jeter, S.C.; Sokoll, L.J.; Garrett-Mayer, E.; Cope, L.M.; Umbricht, C.B.; Euhus, D.M.; et al. Monitoring of serum dna methylation as an early independent marker of response and survival in metastatic breast cancer: TBCRC 005 prospective biomarker study. J. Clin. Oncol. 2017, 35, 751-758. [CrossRef]

148. Shi, J. Considering exosomal MiR-21 as a biomarker for cancer. J. Clin. Med. 2016, 5, 42. [CrossRef]

149. Jang, J.Y.; Kim, Y.S.; Kang, K.N.; Kim, K.H.; Park, Y.J.; Kim, C.W. Multiple MicroRNAs as biomarkers for early breast cancer diagnosis. Mol. Clin. Oncol. 2021, 14, 31. [CrossRef]

150. Estevão-Pereira, H.; Lobo, J.; Salta, S.; Amorim, M.; Lopes, P.; Cantante, M.; Reis, B.; Antunes, L.; Castro, F.; Palma de Sousa, S.; et al. Overexpression of circulating MiR-30b-5p identifies advanced breast cancer. J. Transl. Med. 2019, 17, 435. [CrossRef]

151. Shiino, S.; Matsuzaki, J.; Shimomura, A.; Kawauchi, J.; Takizawa, S.; Sakamoto, H.; Aoki, Y.; Yoshida, M.; Tamura, K.; Kato, K.; et al. Serum MiRNA-based prediction of axillary lymph node metastasis in breast cancer. Clin. Cancer Res. 2019, 25, 1817-1827. [CrossRef]

152. Salvador-Coloma, C.; Santaballa, A.; Sanmartín, E.; Calvo, D.; García, A.; Hervás, D.; Cordón, L.; Quintas, G.; Ripoll, F.; Panadero, J.; et al. Immunosuppressive profiles in liquid biopsy at diagnosis predict response to neoadjuvant chemotherapy in triple-negative breast cancer. Eur. J. Cancer 2020, 139, 119-134. [CrossRef]

153. Özgür, E.; Ferhatoğlu, F.; Şen, F.; Saip, P.; Gezer, U. Circulating LncRNA H19 may be a useful marker of response to neoadjuvant chemotherapy in breast cancer. Cancer Biomark. Sect. Dis. Markers 2020, 27, 11-17. [CrossRef]

154. Bray, F.; Ferlay, J.; Soerjomataram, I.; Siegel, R.L.; Torre, L.A.; Jemal, A. Global cancer statistics 2018: GLOBOCAN estimates of incidence and mortality worldwide for 36 cancers in 185 countries. CA Cancer J. Clin. 2018, 68, 394-424. [CrossRef]

155. Song, L.-L.; Li, Y.-M. Current noninvasive tests for colorectal cancer screening: An overview of colorectal cancer screening tests. World J. Gastrointest. Oncol. 2016, 8, 793-800. [CrossRef] 
156. Nee, J.; Chippendale, R.Z.; Feuerstein, J.D. Screening for colon cancer in older adults: Risks, benefits, and when to stop. Mayo Clin. Proc. 2020, 95, 184-196. [CrossRef]

157. Herreros-Villanueva, M.; Duran-Sanchon, S.; Martín, A.C.; Pérez-Palacios, R.; Vila-Navarro, E.; Marcuello, M.; Diaz-Centeno, M.; Cubiella, J.; Diez, M.S.; Bujanda, L.; et al. Plasma MicroRNA signature validation for early detection of colorectal cancer. Clin. Transl. Gastroenterol. 2019, 10, e00003. [CrossRef]

158. Zhao, G.; Liu, X.; Liu, Y.; Li, H.; Ma, Y.; Li, S.; Zhu, Y.; Miao, J.; Xiong, S.; Fei, S.; et al. Aberrant DNA methylation of SEPT9 and SDC2 in stool specimens as an integrated biomarker for colorectal cancer early detection. Front. Genet. 2020, 11, 643. [CrossRef]

159. Lofton-Day, C.; Model, F.; Devos, T.; Tetzner, R.; Distler, J.; Schuster, M.; Song, X.; Lesche, R.; Liebenberg, V.; Ebert, M.; et al. DNA methylation biomarkers for blood-based colorectal cancer screening. Clin. Chem. 2008, 54, 414-423. [CrossRef]

160. Wang, Y.; Chen, P.-M.; Liu, R.-B. Advance in plasma SEPT9 gene methylation assay for colorectal cancer early detection. World J. Gastrointest. Oncol. 2018, 10, 15-22. [CrossRef]

161. Pickhardt, P.J. Emerging stool-based and blood-based non-invasive DNA tests for colorectal cancer screening: The importance of cancer prevention in addition to cancer detection. Abdom. Radiol. 2016, 41, 1441-1444. [CrossRef]

162. Issa, I.A.; Noureddine, M. Colorectal cancer screening: An updated review of the available options. World J. Gastroenterol. 2017, 23, 5086-5096. [CrossRef]

163. Liu, Y.; Zhao, G.; Miao, J.; Li, H.; Ma, Y.; Liu, X.; Li, S.; Zhu, Y.; Xiong, S.; Zheng, M.; et al. Performance comparison between plasma and stool methylated SEPT9 tests for detecting colorectal cancer. Front. Genet. 2020, 11, 324. [CrossRef] [PubMed]

164. Zhao, G.; Li, H.; Yang, Z.; Wang, Z.; Xu, M.; Xiong, S.; Li, S.; Wu, X.; Liu, X.; Wang, Z.; et al. Multiplex methylated DNA testing in plasma with high sensitivity and specificity for colorectal cancer screening. Cancer Med. 2019, 8, 5619-5628. [CrossRef] [PubMed]

165. Wang, W.; Qu, A.; Liu, W.; Liu, Y.; Zheng, G.; Du, L.; Zhang, X.; Yang, Y.; Wang, C.; Chen, X. Circulating MiR-210 as a diagnostic and prognostic biomarker for colorectal cancer. Eur. J. Cancer Care 2017, 26. [CrossRef] [PubMed]

166. Shi, J.; Li, X.; Zhang, F.; Zhang, C.; Guan, Q.; Cao, X.; Zhu, W.; Zhang, X.; Cheng, Y.; Ou, K.; et al. Circulating LncRNAs associated with occurrence of colorectal cancer progression. Am. J. Cancer Res. 2015, 5, 2258-2265.

167. Bustos, M.A.; Gross, R.; Rahimzadeh, N.; Cole, H.; Tran, L.T.; Tran, K.D.; Takeshima, L.; Stern, S.L.; O’Day, S.; Hoon, D.S.B. A pilot study comparing the efficacy of lactate dehydrogenase levels versus circulating cell-free MicroRNAs in monitoring responses to checkpoint inhibitor immunotherapy in metastatic melanoma patients. Cancers 2020, 12, 3361. [CrossRef]

168. Xing, X.-B.; Cai, W.-B.; Luo, L.; Liu, L.-S.; Shi, H.-J.; Chen, M.-H. The prognostic value of P16 hypermethylation in cancer: A meta-analysis. PLoS ONE 2013, 8, e66587. [CrossRef]

169. Liu, M.C.; Oxnard, G.R.; Klein, E.A.; Swanton, C.; Seiden, M.V. Sensitive and specific multi-cancer detection and localization using methylation signatures in cell-free DNA. Ann. Oncol. 2020, 31, 745-759. [CrossRef]

170. Rasmussen, S.L.; Krarup, H.B.; Sunesen, K.G.; Johansen, M.B.; Stender, M.T.; Pedersen, I.S.; Madsen, P.H.; Thorlacius-Ussing, O. The prognostic efficacy of Cell-Free DNA hypermethylation in colorectal cancer. Oncotarget 2018, 9, 7010-7022. [CrossRef]

171. Barault, L.; Amatu, A.; Siravegna, G.; Ponzetti, A.; Moran, S.; Cassingena, A.; Mussolin, B.; Falcomatà, C.; Binder, A.M.; Cristiano, C.; et al. Discovery of methylated circulating DNA biomarkers for comprehensive non-invasive monitoring of treatment response in metastatic colorectal cancer. Gut 2018, 67, 1995-2005. [CrossRef]

172. Bhangu, J.S.; Beer, A.; Mittlböck, M.; Tamandl, D.; Pulverer, W.; Schönthaler, S.; Taghizadeh, H.; Stremitzer, S.; Kaczirek, K.; Gruenberger, T.; et al. Circulating free methylated tumor DNA markers for sensitive assessment of tumor burden and early response monitoring in patients receiving systemic chemotherapy for colorectal cancer liver metastasis. Ann. Surg. 2018, 268, 894-902. [CrossRef]

173. Young, G.P.; Pedersen, S.K.; Mansfield, S.; Murray, D.H.; Baker, R.T.; Rabbitt, P.; Byrne, S.; Bambacas, L.; Hollington, P.; Symonds, E.L. A cross-sectional study comparing a blood test for methylated BCAT1 and IKZF1 tumor-derived DNA with CEA for detection of recurrent colorectal cancer. Cancer Med. 2016, 5, 2763-2772. [CrossRef]

174. Peng, Q.; Zhang, X.; Min, M.; Zou, L.; Shen, P.; Zhu, Y. The clinical role of MicroRNA-21 as a promising biomarker in the diagnosis and prognosis of colorectal cancer: A systematic review and meta-analysis. Oncotarget 2017, 8, 44893-44909. [CrossRef]

175. Sazanov, A.A.; Kiselyova, E.V.; Zakharenko, A.A.; Romanov, M.N.; Zaraysky, M.I. Plasma and saliva MiR-21 expression in colorectal cancer patients. J. Appl. Genet. 2017, 58, 231-237. [CrossRef]

176. Wang, Q.; Huang, Z.; Ni, S.; Xiao, X.; Xu, Q.; Wang, L.; Huang, D.; Tan, C.; Sheng, W.; Du, X. Plasma MiR-601 and MiR-760 are novel biomarkers for the early detection of colorectal cancer. PLoS ONE 2012, 7, e44398. [CrossRef]

177. Cheng, H.; Zhang, L.; Cogdell, D.E.; Zheng, H.; Schetter, A.J.; Nykter, M.; Harris, C.C.; Chen, K.; Hamilton, S.R.; Zhang, W. Circulating plasma MiR-141 is a novel biomarker for metastatic colon cancer and predicts poor prognosis. PLoS ONE 2011, 6, e17745. [CrossRef]

178. Kou, C.-H.; Zhou, T.; Han, X.-L.; Zhuang, H.-J.; Qian, H.-X. Downregulation of Mir-23b in plasma is associated with poor prognosis in patients with colorectal cancer. Oncol. Lett. 2016, 12, 4838-4844. [CrossRef]

179. Yuan, Z.; Baker, K.; Redman, M.W.; Wang, L.; Adams, S.V.; Yu, M.; Dickinson, B.; Makar, K.; Ulrich, N.; Böhm, J.; et al. Dynamic plasma MicroRNAs Are biomarkers for prognosis and early detection of recurrence in colorectal cancer. Br. J. Cancer 2017, 117, 1202-1210. [CrossRef]

180. Hansen, T.F.; Carlsen, A.L.; Heegaard, N.H.H.; Sørensen, F.B.; Jakobsen, A. Changes in circulating MicroRNA-126 during treatment with chemotherapy and bevacizumab predicts treatment response in patients with metastatic colorectal cancer. $\mathrm{Br}$. $\mathrm{J}$. Cancer 2015, 112, 624-629. [CrossRef] 
181. Svoboda, M.; Slyskova, J.; Schneiderova, M.; Makovicky, P.; Bielik, L.; Levy, M.; Lipska, L.; Hemmelova, B.; Kala, Z.; Protivankova, M.; et al. HOTAIR long non-coding RNA is a negative prognostic factor not only in primary tumors, but also in the blood of colorectal cancer patients. Carcinogenesis 2014, 35, 1510-1515. [CrossRef]

182. Liu, H.; Ye, D.; Chen, A.; Tan, D.; Zhang, W.; Jiang, W.; Wang, M.; Zhang, X. A pilot study of new promising non-coding RNA diagnostic biomarkers for early-stage colorectal cancers. Clin. Chem. Lab. Med. 2019, 57, 1073-1083. [CrossRef]

183. Xu, W.; Zhou, G.; Wang, H.; Liu, Y.; Chen, B.; Chen, W.; Lin, C.; Wu, S.; Gong, A.; Xu, M. Circulating LncRNA SNHG11 as a novel biomarker for early diagnosis and prognosis of colorectal cancer. Int. J. Cancer 2020, 146, 2901-2912. [CrossRef]

184. Salvianti, F.; Orlando, C.; Massi, D.; De Giorgi, V.; Grazzini, M.; Pazzagli, M.; Pinzani, P. Tumor-related methylated cell-free DNA and circulating tumor cells in melanoma. Front. Mol. Biosci. 2015, 2, 76. [CrossRef]

185. Mori, T.; O’Day, S.J.; Umetani, N.; Martinez, S.R.; Kitago, M.; Koyanagi, K.; Kuo, C.; Takeshima, T.-L.; Milford, R.; Wang, H.-J.; et al. Predictive utility of circulating methylated DNA in serum of melanoma patients receiving biochemotherapy. J. Clin. Oncol. 2005, 23, 9351-9358. [CrossRef]

186. Kolenda, T.; Rutkowski, P.; Michalak, M.; Kozak, K.; Guglas, K.; Ryś, M.; Galus, Ł.; Woźniak, S.; Ługowska, I.; Gos, A.; et al. Plasma LncRNA expression profile as a prognostic tool in BRAF-mutant metastatic melanoma patients treated with BRAF inhibitor. Oncotarget 2019, 10, 3879-3893. [CrossRef]

187. Manoochehri, M.; Wu, Y.; Giese, N.A.; Strobel, O.; Kutschmann, S.; Haller, F.; Hoheisel, J.D.; Moskalev, E.A.; Hackert, T.; Bauer, A.S. SST gene hypermethylation acts as a pan-cancer marker for pancreatic ductal adenocarcinoma and multiple other tumors: Toward its use for blood-based diagnosis. Mol. Oncol. 2020, 14, 1252-1267. [CrossRef]

188. Giannopoulou, L.; Kasimir-Bauer, S.; Lianidou, E.S. Liquid biopsy in ovarian cancer: Recent advances on circulating tumor cells and circulating tumor DNA. Clin. Chem. Lab. Med. 2018, 56, 186-197. [CrossRef]

189. Wang, L.; Chen, Y.-J.; Xu, K.; Xu, H.; Shen, X.-Z.; Tu, R.-Q. Circulating MicroRNAs as a fingerprint for endometrial endometrioid adenocarcinoma. PLoS ONE 2014, 9, e110767. [CrossRef]

190. Nassiri, F.; Chakravarthy, A.; Feng, S.; Shen, S.Y.; Nejad, R.; Zuccato, J.A.; Voisin, M.R.; Patil, V.; Horbinski, C.; Aldape, K.; et al. Detection and discrimination of intracranial tumors using plasma cell-free DNA methylomes. Nat. Med. 2020, 26, $1044-1047$. [CrossRef]

191. Hegi, M.E.; Diserens, A.-C.; Gorlia, T.; Hamou, M.-F.; de Tribolet, N.; Weller, M.; Kros, J.M.; Hainfellner, J.A.; Mason, W.; Mariani, L.; et al. MGMT gene silencing and benefit from temozolomide in glioblastoma. N. Engl. J. Med. 2005, 352, 997-1003. [CrossRef]

192. Kopkova, A.; Sana, J.; Machackova, T.; Vecera, M.; Radova, L.; Trachtova, K.; Vybihal, V.; Smrcka, M.; Kazda, T.; Slaby, O.; et al. Cerebrospinal fluid MicroRNA signatures as diagnostic biomarkers in brain tumors. Cancers 2019, 11, 1546. [CrossRef]

193. Lim, Y.; Wan, Y.; Vagenas, D.; Ovchinnikov, D.A.; Perry, C.F.L.; Davis, M.J.; Punyadeera, C. Salivary DNA Methylation panel to diagnose HPV-positive and HPV-negative head and neck cancers. BMC Cancer 2016, 16, 749. [CrossRef] [PubMed]

194. Chen, X.; Gole, J.; Gore, A.; He, Q.; Lu, M.; Min, J.; Yuan, Z.; Yang, X.; Jiang, Y.; Zhang, T.; et al. Non-invasive early detection of cancer four years before conventional diagnosis using a blood test. Nat. Commun. 2020, 11, 3475. [CrossRef] [PubMed]

195. García-Giménez, J.L.; Seco-Cervera, M.; Tollefsbol, T.O.; Romá-Mateo, C.; Peiró-Chova, L.; Lapunzina, P.; Pallardó, F.V. Epigenetic biomarkers: Current strategies and future challenges for their use in the clinical laboratory. Crit. Rev. Clin. Lab. Sci. 2017, 54, 529-550. [CrossRef] [PubMed] 